\title{
Phylogeny and molecular signatures (conserved proteins and indels) that are specific for the Bacteroidetes and Chlorobi species Radhey S Gupta* and Emily Lorenzini
}

\author{
Address: Department of Biochemistry and Biomedical Science, McMaster University, Hamilton, L8N3Z5, Canada \\ Email: Radhey S Gupta* - gupta@mcmaster.ca; Emily Lorenzini - lorenze@muss.cis.mcmaster.ca \\ * Corresponding author
}

Published: 8 May 2007

BMC Evolutionary Biology 2007, 7:7| doi:|0.|186/|47|-2|48-7-7|
Received: 21 December 2006

Accepted: 8 May 2007

This article is available from: http://www.biomedcentral.com/|47|-2/48/7/7I

(C) 2007 Gupta and Lorenzini; licensee BioMed Central Ltd.

This is an Open Access article distributed under the terms of the Creative Commons Attribution License (http://creativecommons.org/licenses/by/2.0), which permits unrestricted use, distribution, and reproduction in any medium, provided the original work is properly cited.

\begin{abstract}
Background: The Bacteroidetes and Chlorobi species constitute two main groups of the Bacteria that are closely related in phylogenetic trees. The Bacteroidetes species are widely distributed and include many important periodontal pathogens. In contrast, all Chlorobi are anoxygenic obligate photoautotrophs. Very few (or no) biochemical or molecular characteristics are known that are distinctive characteristics of these bacteria, or are commonly shared by them.

Results: Systematic blast searches were performed on each open reading frame in the genomes of Porphyromonas gingivalis W83, Bacteroides fragilis YCH46, B. thetaiotaomicron VPI-5482, Gramella forsetii KT0803, Chlorobium luteolum (formerly Pelodictyon luteolum) DSM 273 and Chlorobaculum tepidum (formerly Chlorobium tepidum) TLS to search for proteins that are uniquely present in either all or certain subgroups of Bacteroidetes and Chlorobi. These studies have identified $>600$ proteins for which homologues are not found in other organisms. This includes 27 and 51 proteins that are specific for most of the sequenced Bacteroidetes and Chlorobi genomes, respectively; 52 and 38 proteins that are limited to species from the Bacteroidales and Flavobacteriales orders, respectively, and 5 proteins that are common to species from these two orders; 185 proteins that are specific for the Bacteroides genus. Additionally, 6 proteins that are uniquely shared by species from the Bacteroidetes and Chlorobi phyla (one of them also present in the Fibrobacteres) have also been identified. This work also describes two large conserved inserts in DNA polymerase III (DnaE) and alanyl-tRNA synthetase that are distinctive characteristics of the Chlorobi species and a 3 aa deletion in ClpB chaperone that is mainly found in various Bacteroidales, Flavobacteriales and Flexebacteraceae, but generally not found in the homologs from other organisms. Phylogenetic analyses of the Bacteroidetes and Chlorobi species is also reported based on concatenated sequences for 12 conserved proteins by different methods including the character compatibility (or clique) approach. The placement of Salinibacter ruber with other Bacteroidetes species was not resolved by other phylogenetic methods, but this affiliation was strongly supported by the character compatibility approach.

Conclusion: The molecular signatures described here provide novel tools for identifying and circumscribing species from the Bacteroidetes and Chlorobi phyla as well as some of their main groups in clear terms. These results also provide strong evidence that species from these two phyla (and also possibly Fibrobacteres) are specifically related to each other and they form a single superphylum. Functional studies on these proteins and indels should aid in the discovery of novel biochemical and physiological characteristics that are unique to these groups of bacteria.
\end{abstract}




\section{Background}

The Bacteroidetes and Chlorobi presently comprise two of the main phyla within the Bacteria [1-3]. The bacteria from the Bacteroidetes phylum (previously known as the Cytophaga-Flavobacteria-Bacteroides (CFB) group) exhibit a potpourri of phenotypes including gliding behavior and their ability to digest and grow on a variety of complex substrates such as cellulose, chitin and agar [4-8]. They inhabit diverse habitats including the oral cavity of humans, the gastrointestinal tracts of mammals, saturated thalassic brines, soil and fresh water [9-13]. The Bacteroides species such as $B$. thetaiotaomicron and $B$. fragilis are among the dominant microbes in the large intestine of human and other animals $[14,15]$. These bacteria in the human colon are also important opportunistic pathogens and they are involved in causing abscesses and soft tissue infections of the gastrointestinal tract, as well as diarrheal diseases [15-18]. Other bacteroidetes species, such as Porphyromonas gingivalis and Prevotella intermedia, are major causative agents in the initiation and progression of periodontal disease in humans $[12,19,20]$.

In contrast to wide distribution of Bacteroidetes species in diverse habitats, bacteria from the phylum Chlorobi occupy a narrow environmental niche mainly consisting of anoxic aquatic settings in stratified lakes (chemocline regions), where sunlight is able to penetrate [21-24]. Some of these bacteria also exist as epibionts in phototrophic consortiums with other bacteria, particularly $\beta$ proteobacteria $[21,25]$. The Chlorobi, which are also commonly known as Green Sulfur bacteria, are all anoxygenic obligate photoautotrophs, which obtain electrons for anaerobic photosynthesis from hydrogen sulfide $[22,23,26]$. Although the Bacteroidetes and Chlorobi are presently recognized as two distinct phyla [1,3], these two groups are closely related in phylogenetic trees based on $16 S$ rRNA as well other gene sequences [27-30]. Conserved indels (i.e. inserts or deletions) in a number of widely distributed proteins (viz. FtsK, UvrB and ATP synthase $\alpha$ subunit), that are uniquely present in species from these two groups, also strongly indicate that these two groups of species shared a common ancestor exclusive of all other bacteria [30].

The species from the Bacteroidetes and Chlorobi phyla are presently distinguished from other bacteria primarily on the basis of their branching in phylogenetic trees [2,3,27]. We have previously described a 4 aa conserved insert in DNA Gyrase B as well as a 45 aa conserved insert in SecA protein that were specific for the Bacteroidetes species [30]. In Chlorobi as well as Chloroflexi species, their light harvesting pigments are located in unique membrane-attached sac-like structures referred to as 'chlorosomes' $[22,24,31,32]$. A number of genes involved in the synthesis of chlorosomes components in Chlorobi have been identified by genomic and mutational analysis [26] and a few of them, viz. Fenna-Matthew-Olson (FMO) protein [33], are unique for this group [32,34]. However, the number of characteristics that are either unique to species from these two phyla, or are commonly shared by members of these phyla, are very limited. In the past few years, complete genomes of several Bacteroidetes and Chlorobi species have become available (see Table 1). Additionally, sequencing of genomes for many other Bacteroidetes/Chlorobi species is at different stages of completion (see Table 1 ), but considerable sequence information for these genomes is available in the NCBI database.

The availability of genomic sequences provide an opportunity to carry out in depth studies to identify novel molecular characteristics that are unique to these groups of bacteria and can be used for their diagnostics as well as biochemical and functional studies. Earlier comparative genomic studies on Bacteroidetes/Chlorobi species have been limited to only a few species and they have focused on specific aspects. The studies by Kuwahara [35] and Cerdeño-Tárraga et al. [16], who sequenced the genomes of $B$. fragilis strains, revealed that these genomes contained extensive DNA inversions in comparison to B. thetaiotaomicron. These inversion events are indicated to be important in terms of generating cell surface variability in these bacteria to avoid their recognition by the immune system. Large expansion of genes involved in the biosynthesis of cell surface polysaccharides and other antigens was also noted in these genomes $[16,35]$. A comparative analysis by Eisen et al. [24] of C. tepidum TLS genome identified many probable cases of lateral gene transfers (LGTs) between this species and Archaea; in all about $12 \%$ of $C$. tepidum's proteins were indicated to be most similar to those from the archaea. Similarly, the analysis of $S$. ruber genome by Mongodin et al. [36] has identified many cases of potential LGT between $S$. ruber and haloarchaea, particularly involving the rhodopsin genes.

In our recent work, we have used comparative genomics to systematically identify various proteins that are uniquely found in either all members, or particular subgroups, of a number of important groups of prokaryotes. These studies have identified large number of proteins that are specific for alpha proteobacteria [37], chlamydiae [38], Actinobacteria [39], epsilon proteobacteria [40] and Archaea [41]. Such genes and proteins, because of their specificity for different phylogenetic or taxonomic groups, provide novel means for diagnostics and evolutionary studies $[38,39,42-44]$ and for the discovery of important biochemical and physiological characteristics that are unique to these groups of prokaryotes. However, thus far no comparative study has examined different genes/proteins that are uniquely present in species from the Bacteroidetes and Chlorobi phyla or are commonly shared by 
Table I: General Characteristics of Bacteroidetes/Chlorobi Genomes

\begin{tabular}{|c|c|c|c|c|c|c|}
\hline & Strain Name & Taxonomic Order & $\begin{array}{c}\text { Genome } \\
\text { Size }(\mathbf{M b})^{* *}\end{array}$ & $\begin{array}{c}\text { GC } \\
\text { Content (\%) }\end{array}$ & $\begin{array}{l}\text { Protein } \\
\text { Number }\end{array}$ & Reference\# \\
\hline \multirow[t]{17}{*}{ Bacteroidetes } & Porphyromonas gingivalis W83\# & Bacteroidales & 2.34 & 48.3 & 1909 & [58] \\
\hline & Bacteroides fragilis NCTC $9343^{\#}$ & & 5.24 & 44 & 4184 & {$[16]$} \\
\hline & Bacteroides fragilis $\mathrm{YCH} 46^{\#}$ & & 5.31 & 33.5 & 4578 & [35] \\
\hline & Bacteroides thetaiotaomicron VPI-5482\# & & 6.29 & 42 & 4778 & {$[15]$} \\
\hline & Gramella forsetii KT0803\# & Flavobacteriales & 3.8 & 36.6 & 3559 & [59] \\
\hline & Flavobacteria bacterium BBFL7* & & 5 & 35.0 & 2592 & a \\
\hline & Flavobacteriales bacterium HTCC2170* & & 5 & 37.0 & 3478 & a \\
\hline & Flavobacterium johnsoniae UWIOI* & & - & 35.2 & 4985 & DOE-JGI \\
\hline & Flavobacterium sp. MED $2 \mid 7^{*}$ & & 5 & 39.8 & 3735 & $\mathrm{a}$ \\
\hline & Cellulophaga sp. MEDI34* & & 5 & 38.2 & 2944 & $\mathrm{a}$ \\
\hline & Croceibacter atlanticus HTCC2559* & & 5 & 33.9 & 2719 & a \\
\hline & Polaribacter irgensii $23-\mathrm{P}^{*}$ & & - & 31.0 & 2557 & $\mathrm{a}$ \\
\hline & Psychroflexus torquis ATCC $700755^{*}$ & & 5 & $32-33.0$ & 6751 & $\mathrm{a}$ \\
\hline & Robiginitalea biformata HTCC250I* & & 5 & 56.4 & 3228 & a \\
\hline & Tenacibaculum sp. MEDI52* & & 5 & 30.6 & 2679 & $\mathrm{a}$ \\
\hline & Cytophaga hutchinsonii ATCC $33406^{\#}$ & Sphingobacteriales & 4.43 & 38.8 & 3785 & CP000383 \\
\hline & Salinibacter ruber DSM I3855\# & & 3.59 & 66.5 & 2801 & {$[36]$} \\
\hline \multirow[t]{9}{*}{ Chlorobi } & Chlorobium chlorochromatii CaD3\# & Chlorobia & 2.57 & 44.3 & 2002 & CP000108 \\
\hline & Chlorobium limicola DSM 245* & & 2.4 & 51.3 & 2435 & DOE-JGI \\
\hline & Chlorobium phaeobacteroides BSI* & & 2. & 45.5 & 3791 & DOE-JGI \\
\hline & Chlorobium phaeobacteroides DSM 266* & & 2.4 & 48.3 & 2789 & DOE-JGI \\
\hline & $\begin{array}{l}\text { Chlorobaculum tepidum formerly Chlorobium } \\
\text { tepidum TLS\# }\end{array}$ & & 2.15 & 56 & 2252 & {$[24]$} \\
\hline & $\begin{array}{l}\text { Chlorobium luteolum formerly Pelodictyon } \\
\text { luteolum DSM } 273^{\#}\end{array}$ & & 2.36 & 57.3 & 2083 & CP000096 \\
\hline & $\begin{array}{l}\text { Chlorobium clathratiforme formerly } \\
\text { Pelodictyon phaeoclathratiforme BU-I* }\end{array}$ & & - & 48.1 & 2762 & DOE-JGI \\
\hline & Prosthecochloris aestuarii DSM 27I* & & - & 50.1 & 2313 & DOE-JGI \\
\hline & $\begin{array}{l}\text { Chlorobium phaeovibrioides formerly } \\
\text { Prosthecochloris vibrioformis DSM } 265^{*}\end{array}$ & & - & 53.0 & 1747 & DOE-JGI \\
\hline
\end{tabular}

\#Indicates a completely sequenced genome. The references to the published genomes are provided. For others that are fully sequenced but not published, accession numbers for the genomes are given.

* Indicates that these genomes are at draft assembly stages. The information regarding genome sizes etc. in these cases have been obtained from the $\mathrm{NCBI}$ microbial sequence database.

The revised names for a number of Chlorobi species are as proposed in Ref. 45.

\# The sequences marked 'a' are being sequenced by Gordon and Betty Moore Foundation Marine Biotechnology Intiative; DOE-JGE, indicates Department of Energy Joint Genome Institute. For some of the completed genomes, which are not published, their accession numbers are provided.

species from these two groups. In order to identify proteins that are uniquely found in the Bacteroidetes and/or Chlorobi groups of species, we have carried out systematic blast searches on all open reading frames in the genomes of $P$. gingivalis W83, B. fragilis $\mathrm{YCH} 46, B$. thetaiotaomicron VPI-5482, G. forsetii KT0803, C. luteolum DSM 273 and C. tepidum TLS against all available sequences in the NCBI non-redundant (nr) database. This has led to identification of large numbers of proteins that are distinctive characteristics of species from different taxonomic groups within the Bacteroidetes phylum (e.g. specific for the Bacteroides genus, specific for the Bacteroidales and Flavobacteriales orders, or specific for the entire Bacteroidetes phylum). Additionally, large numbers of proteins that are specific for the Chlorobi species as well as some proteins that are uniquely shared by the Bacteroidetes and Chlorobi phyla have also been identified. This work also describes three conserved indels in important housekeeping proteins (viz. alanyl-tRNA synthetase, DNA polymerase subunit III and $\mathrm{ClpB}$ ) that are distinctive characteristics of either the Chlorobi or the Bacteroidales-FlavobacterialesFlexebacteraceae groups. Phylogenetic analyses of the Bacteroidetes and Chlorobi were also carried out based on a concatenated sequence alignment for 12 highly conserved proteins and the results of these analyses support the inferences derived from the species distribution of various molecular signatures.

\section{Results \\ Phylogenetic analyses of Bacteroidetes and Chlorobi species}

Table 1 lists some characteristics of various Bacteroidetes and Chlorobi genomes that have been completely sequenced as well as for many others that are currently 
being sequenced. The taxonomy of the Chlorobi species has undergone significant revision in the past few years leading to name changes and new taxonomic groupings for a number of species [45]. The newly proposed and former names for some of the species that will be discussed in the present work are as follows: Chlorobium tepidum changed to Chlorobaculum tepidum; Pelodictyon luteolum changed to Chlorobium luteolum; Prosthecochloris vibrioformis changed to Chlorobium phaeovibrioides; Pelodictyon phaeoclathratiforme changed to Chlorobium clathratiforme. Although many of these species in the databases are still referred to by their former names, we have used the revised nomenclature in our work to interpret the results of evolutionary and comparative genomic studies.

Prior to undertaking comparative analyses of Bacteroidetes and Chlorobi genomes, phylogenetic analyses on these species were carried out to get an overview of their evolutionary relationships, which can serve as a reference point for comparative genomic analyses. Phylogenetic analysis of Bacteroidetes and Chlorobi species has been carried out previously using $16 \mathrm{~S}$ rRNA sequences and a few isolated protein sequences [27-30,46-49]. However, recent studies show that analyses based on larger dataset derived from multiple genes/proteins sequences provide a more reliable phylogenetic inference [50]. Hence, phylogenetic analyses for these species was carried out based on concatenated sequences for 12 highly conserved proteins involved in a broad range of functions (see Methods section). The final sequence alignment for phylogenetic analysis contained a total of 6998 aligned positions.

Phylogenetic trees were constructed using the neighbourjoining (NJ), maximum-likelihood (ML) and maximumparsimony (MP) methods [51]. The results of these analyses for the NJ and ML methods are presented in Fig. 1. The trees were rooted using the sequences for DeinococcusThermus species. The tree in both cases consisted of two well-resolved clades (100\% bootstrap scores by both treeing methods), one comprising of various Chlorobi species and the other containing various Cytophaga-Flavobacteria-Bacteroides (CFB) species. In these trees, $S$. ruber appeared as a deep branching outgroup of the Chlorobi clade, but in view of the low bootstrap score of the node indicating this relationship and the long branch that separated them, this relationship was not reliable. The topology of various species in the MP tree was very similar, except that in this tree $S$. ruber formed the outgroup of Chlorobi as well as various other CFB group of bacteria (results not shown). In addition to the uncertain position of $S$. ruber, different species belonging to the genus Flavobacterium did not form a coherent phylogenetic group (Fig. 1). For most other Bacteroidetes species, sequence information for multiple species from the same genera was not available.

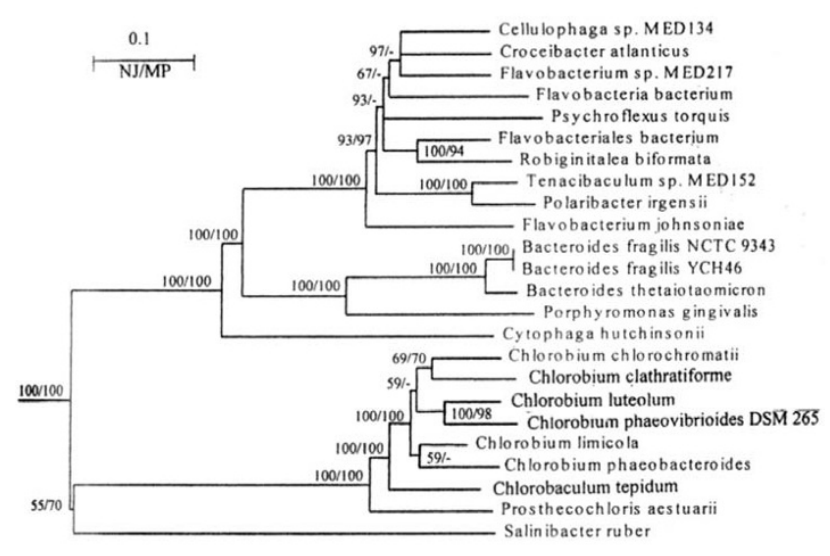

\section{Figure I}

Neighbour-joining tree based on concatenated sequences for 12 highly conserved proteins. The tree was rooted using sequences for Deinococcus-Thermus species and numbers on the nodes indicate bootstrap scores in the $\mathrm{NJ}$ and maximumlikelihood analyses (NJ/MP). The branching position of $G$. forsetii, which became available after this analysis was completed, is not shown. However, our analysis of a smaller dataset indicates that it exhibits closest affinity for the flavobacteria Psychrobacter torquis (results not shown).

Phylogenetic analysis on the concatenated dataset was also performed employing the character compatibility approach [52]. In this approach, all sites in the sequence alignment where only two amino acid states are found, with each state present in at least two species, are examined for mutual compatibility to find the largest clique of mutually compatible characters [52-56]. By removing all homoplasic as well as fast-evolving characters from dataset, this approach provides a powerful means for obtaining correct topology in difficult to resolve cases [56,57]. Our concatenated dataset for the 12 proteins contained 832 positions where only two amino acids were found, with each amino acid present in a minimum of two species. The mutual compatibility of these binary state sites was determined as described in the Methods section.

The compatibility analysis identified two largest sets of compatible characters (referred to as cliques) each containing 410 characters. These cliques were identical in all respects except that the relative branching positions of Chlorobaculum tepidum and Chlorobium chlorochromatii, which differed by a single character, were interchanged. A composite of these cliques, in which the branching positions of these two species are not resolved, is shown in Fig. 2. A large number of characters (i.e. 200) in this clique distinguished the Chlorobi-Bacteroidetes species from the two Deinococcus-Thermus species, which were included to serve as outgroup. The clique is comprised of two main clades, one consisting of various species belonging to the Bacter- 
oidetes group and the other of different Chlorobi species. The species from each of these clades were distinguished by a large numbers of characters. In the Bacteroidetes clade, $S$. ruber was found to be the deepest branching lineage and its specific association with other Bacteroidetes species was supported by 21 uniquely shared characters, which is a highly significant result [57]. Additionally, the two main orders within the Bacteroidetes viz. Bacteriodales and Flavobacteriales, for which sequence information is available from multiple species, were clearly distinguished based upon multiple characters. However, these analyses detected no uniquely shared character between the $C$. hutchinsonii and S. ruber. Although, these two species are currently placed in the order Sphingobacteriales, phylogenetic trees do not support a specific grouping of them (see Fig. 1). Different Flavobacterium species again did not group together indicating that this genus does not constitute a phylogenetically coherent taxon. Within the Chlorobi clade, Prosthecochloris aesturaii was found to be the deepest branching lineage, but branching order of other Chlorobi species was not resolved.

\section{Comparative Genomic Studies on Bacteroidetes and Chlorobi Species}

To identify proteins that are uniquely present in species from the Bacteroidetes and Chlorobi phyla at various taxonomic levels (genus and above), systematic Blastp searches were performed on each protein or ORF in the genomes of the following species: Bacteroides (P. gingivalis W83 [58], B. fragilis YCH46 [35], B. thetaiotaomicron VPI-

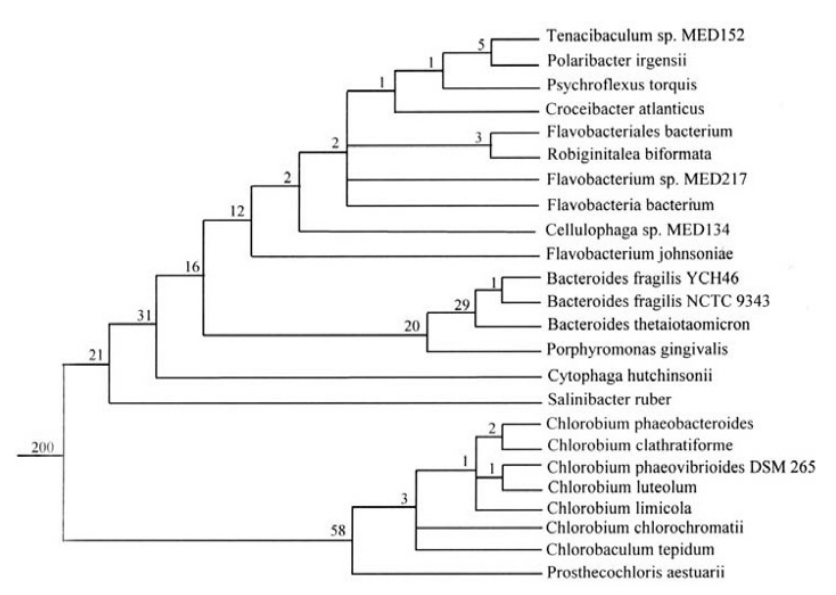

Figure 2

Character compatibility tree (or the largest clique of mutually compatible characters) based on two states sites in the concatenated sequence alignment for the 12 proteins. The clique consisted of 410 mutually compatible characters. The numbers of characters that distinguished different clades are indicated on the nodes. Rooting was done using the sequences for Deinococcus-Thermus species.
5482 [15]); Flavobacteria (G. forsetii str. KT0803 [59]); Chlorobi (C. luteolum DSM 273 and C. tepidum TLS [24]). These analyses have identified a large number of proteins that are specific for different taxonomic groups. A brief description of these signature proteins and their evolutionary significances are discussed below.

\section{Proteins (or ORFs) that are Specific for the Species within the Bacteroidetes Phylum}

The blast searches on various ORFs from $P$. gingivalis, $B$. fragilis $\mathrm{YCH} 46$ and $B$. thetaiotaomicron genomes have identified 27 proteins that are present in most of the species from the Bacteroidetes phylum (Table 2). In addition to most fully sequenced Bacteroidetes genomes, the homologs of these proteins are also present in most Bacteroidetes species whose genomes have been partially sequenced. One of these proteins, PG0448, is present in all of the Bacteroidetes species, whose genomes have been either partially or fully sequenced. Two other proteins, PG1850 and PG2092, are present in all fully as well as partially sequenced genomes, except those from the Bacteroides genus. The absence of these proteins in only the species from this genus is very likely due to selective gene loss from this lineage and their genes also likely originated in a common ancestor of the Bacteroidetes phylum. Similarly, four proteins viz. PG0449, PG0779, PG1679 and PG2066, are present in virtually all other Bacteroidetes genomes, but they are missing in C. hutchinsonii. Their absence again is very likely due to selective gene loss from C. hutchinsonii. Eight additional proteins viz. PG0202, PG0362, PG0399, PG0482, PG0621, PG01281, PG1367 and PG1394, are present in all other fully as well as partially sequenced Bacteroidetes genomes, but they are only missing in $S$. ruber. The absence of these proteins in $S$. ruber can also be explained by selective gene loss. However, in view of the fact that $S$. ruber branches very deeply in comparison to all other Bacteroidetes species (Figs. 1 and 2), it is also possible that their genes evolved in a common ancestor of the other Bacteroidetes species after the divergence of $S$. ruber.

We have also come identified a 3 aa deletion in a conserved region of $\mathrm{ClpB}$ protease that is present in all other Bacteroidetes species, except S. ruber (Additional file 1). Similar to the genes for the above 8 proteins, this deletion likely occurred in a common ancestor of the other Bacteroidetes species after the branching of $S$. ruber. Besides Bacteroidetes species, this indel is also present in the ClpB homologs from C. phaebacteroidetes (only Chlorobi species containing this protein) and the archaeum Methanospirillum hungatei, which is likely due to LGT. The remaining proteins in Table 2, of which 7 (BF0751, BF1057, BF1327, BF3185; BF1254, BF3612, BF4330) are homologous to each other, are missing in 1 or 2 sequenced species (e.g. $P$. gingivalis, B. fragilis, C. hutchinsonii or S. ruber) and their 
Table 2: Proteins that are Specific for the Phylum Bacteroidetes

\begin{tabular}{|c|c|c|c|c|}
\hline Protein Name & Accession No. & Length & Possible/Predicted Function & Comments \\
\hline PG0202 & NP 904537 & 165 & $\begin{array}{l}\text { Uroporphyrinogen-III synthase HemD, putative; } \\
\text { COGI587, HemD; pfam02602, HEM4 }\end{array}$ & Missing in S. ruber ${ }^{+}$ \\
\hline PG0362 & NP 904673 & 722 & Hypothetical & Missing in S. ruber \\
\hline PG0399 & NP 904705 & 156 & Putative lipoprotein & Missing in S. ruber \\
\hline PG0448 & NP 904748 & 434 & $\begin{array}{l}\text { Toluene } \times \text { outer membrane/transport protein } \\
\text { (OMPPI/FadL/TodX); pfam03349 }\end{array}$ & All species present \\
\hline PG0449 & NP 904749 & 441 & $\begin{array}{l}\text { TPR domain protein; cd00I89, TPR; COG307I, } \\
\text { HemY; COG4783, Putative Zn-dependent protease }\end{array}$ & Not found in $F$. johnsoniae and $C$. hutchinsonii \\
\hline PG0482 & NP 904777 & 143 & Hypothetical protein & Missing in S. ruber \\
\hline PG0621 & NP 904906 & 182 & Hypothetical protein & Missing in S. ruber \\
\hline PG0779 & NP 905041 & 157 & ExbD, Biopolymer transport protein; COG0848 & $\begin{array}{l}\text { Not found in F. bacterium HTC, F. johnsoniae } \\
\text { and } C \text {. hutchinsonii }\end{array}$ \\
\hline PGI28I & NP 905462 & 387 & $\begin{array}{l}\text { Putative DNA mismatch repair protein; pfam017I3, } \\
\text { Smr; COGII93, Mismatch repair ATPase }\end{array}$ & Not found in C. atlanticus and S. ruber ${ }^{+}$ \\
\hline PG I367 & NP 905532 & 200 & Hypothetical protein & Missing in S. ruber \\
\hline PGI394 & NP 905555 & 165 & Putative trans-membrane & Missing in S. ruber \\
\hline PGI626 & NP 905755 & 554 & Putative hemin receptor & $\begin{array}{l}\text { Missing in } C \text {. hutchinsonii; also present in } C \text {. } \\
\text { phaeobacteriodes. }\end{array}$ \\
\hline PG I679 & NP 905797 & 464 & Putative trans-membrane & Not found in $P$. ruminicola and $C$. hutchinsonii \\
\hline PG 1850 & NP 905940 & 302 & Hypothetical protein & Missing in Bacteroides species ${ }^{+}$ \\
\hline PG2066 & NP 906128 & 351 & Putative lipoprotein & Missing in $P$. ruminicola and $C$. hutchinsonii \\
\hline PG2092 & NP 906153 & 419 & Hypothetical protein & Missing in Bacteroides species \\
\hline BF0296 & YP 097579 & 988 & Outer membrane assembly protein & Missing in $P$. gingivalis and S. ruber ${ }^{+}$ \\
\hline BF0439 & YP 097722 & 565 & $\begin{array}{l}\text { Putative outer membrane protein probably involved in } \\
\text { nutrient binding }\end{array}$ & Missing in P. gingivalis, and Tenacibaculum \\
\hline BF0534 & YP 097817 & 192 & Putative acetyl-transferase & $\begin{array}{l}\text { Missing in } P \text {. gingivalis, } C \text {. atlanticus and } S \text {. } \\
\text { ruber }\end{array}$ \\
\hline BF0665 & YP 097947 & 531 & Putative exported protein & Missing in $P$. gingivalis, and $C$. hutchinsonii \\
\hline BF075I & YP 098036 & 577 & Putative exported protein & $\begin{array}{l}\text { Missing in } P \text {. gingivalis, P. torquis, } R \text {. biformata } \\
\text { and } C \text {. hutchinsonii }\end{array}$ \\
\hline BFI057 & YP 098341 & 506 & Putative exported protein & Missing in $P$. gingivalis, and $C$. hutchinsonii \\
\hline BFI 254 & YP 098538 & 507 & Putative exported protein & Missing in $P$. gingivalis, and $C$. hutchinsonii \\
\hline BFI327 & YP 098610 & 514 & Putative exported protein & Missing in $P$. gingivalis, and $C$. hutchinsonii \\
\hline $\mathrm{BF} 3185$ & YP 100464 & 490 & Putative exported protein & Missing in $P$. gingivalis, and $C$. hutchinsonii \\
\hline $\mathrm{BF} 3612$ & $\underline{Y P 100889}$ & 542 & Putative exported protein & Missing in $P$. gingivalis and $C$. hutchinsonii \\
\hline BF4330 & YP 101602 & 538 & Putative exported protein & $\begin{array}{l}\text { Missing in } P \text {. gingivalis, } R \text {. biformata and } C \text {. } \\
\text { hutchinsonii }\end{array}$ \\
\hline
\end{tabular}

For the proteins listed here, all significant blast hits are from various Bacteroidetes species, except as noted below. These proteins are present in all of the Bacteroidetes species listed in Table I, except as noted in the comments.

+For the protein PG0202, a significant hit is also observed from C. phaeobacteroides; For BF0296 significant hits also observed from P. aestuarii and C. phaeobacteroides.

Of the proteins listed here, the following proteins are homologous to each other: BF075I, BFI057, BFI327, BF3 I85; BFI254, BF36I2, BF4330.

distribution pattern can also be explained by similar mechanisms as discussed above. Except for a few proteins that show limited similarity to conserved domains (CDs) found in other proteins [60], most of the proteins in Table 2 are of unknown function.

These searches have also identified several proteins that at present appear unique for the species from the Bacteroidales and Flavobacteriales orders. These proteins are listed in Table 3. Of these, the first 4 proteins viz. PG0336, PG1302, PG1537, PG2030 are present in nearly all complete as well as partially sequenced species from the above two orders, but they are not found in $S$. ruber as well as $C$. hutchinsonii. The latter two species, which show much deeper branching than all other Bacteroidales species (Figs. 1 and 2), are currently placed in the order Sphingobacteriales. The genes for the proteins listed in Table 3 have thus likely originated in a common ancestor of the Bacteroidales and Flavobacteriales after the divergence of Sphingobacteria. Thirty-seven additional proteins in Table 3 are also uniquely present in either all or many of the sequenced Bacteroidales species and a small number of flavobacteria species including G. forsetii. A large number of these proteins are only missing in $P$. gingivalis, which is likely due to gene loss. Of the proteins listed in Table 3, seven are indicated to be conjugative transposon proteins: TraJ, TraN, TraK, TraF, TraE and TraB (PG1251 and PG1479, PG1475, PG1478, PG1482, PG1483 and BF0127, respec- 
tively). Four of them are present in two clusters very close to each other (PG1478-PG1479, PG1482-PG1483), supporting their involvement in related functions $[61,62]$. The genes for these proteins have also likely evolved in a common ancestor of the Bacteroidales and Flavobacteriales, followed by gene losses in various species.

\section{Proteins that are specific for the order Bacteroidales or the genus} Bacteroides

There are 4 genomes for the Bacteroidales species ( $P$. gingivalis W83, B. thetaiotaomicron VPI-5482 and B. fragilis strains: NCTC 9343 and YCH46) that have been fully sequenced. Additionally, sequence information for a large number of genes/proteins from Prevotella intermedia 17 and Prevotella ruminicola 23, which belong to this order is available in the in NCBI database (see Table 1). Our blast searches on proteins from $P$. gingivalis genome have identified 52 proteins that are uniquely shared by either all or most of the sequenced Bacteriodales species and whose homologs are not found in any other species, except where noted (Table 4). Thirty-nine of these 52 proteins are uniquely found in all 4 fully sequenced Bacteroidales species. These species also form a strongly supported clade in phylogenetic trees (Figs. 1 and 2). Thus, it is likely that the genes for these proteins evolved in a common ancestor of this order. The remaining 13 proteins are lacking in at least one of the Bacteroides species (noted in Table 4), which is likely due to gene loss. In addition to the sequenced Bacteroidales species, high scoring homologs for many of the above proteins were also found in the two Prevotella species. These latter homologs were detected via genomic blasts against partially sequenced genomes from these species (see Methods).

The majority of the Bacteroidales-specific proteins are hypothetical and some of them are indicated as putative exported proteins (Table 4). Some interesting proteins in this list include the FimX proteins (PG2130, PG2168) that are involved in fimbriae production, which is necessary for adhesion to host surfaces [63]. Also of interest is the

Table 3: Proteins that are Specific for the Bacteroidales and Flavobacteriales Orders

\begin{tabular}{|c|c|c|c|}
\hline $\begin{array}{l}\text { Genome ID No. } \\
\text { [Accession No.] }\end{array}$ & Possible/Predicted Function & $\begin{array}{l}\text { Genome ID No. } \\
\text { [Accession No.] }\end{array}$ & Possible/Predicted Function \\
\hline PG0336 [NP 904650] & Hypothetical protein & PGI276 [NP 905457] & DNA-binding protein, histone-like family \\
\hline PGI302 [NP 905476] & Hypothetical protein & PGI389 [NP 90555I] & DNA-binding protein, histone-like family \\
\hline PGI537 [NP_905677] & Hypothetical protein & PGI444 [NP 905595] & Hypothetical protein \\
\hline PGI25I [NP 905435] & Conjugative transposon protein TraJ & PGI475 [NP 90562I] & Conjugative transposon protein $\mathrm{TraN}$ \\
\hline PG2030 [NP 906097] & Hypothetical protein & PGI478 [NP 905624] & Conjugative transposon protein TraK \\
\hline PGI492 [NP 905638] & Hypothetical protein & PGI479 [NP 905625] & Conjugative transposon protein TraJ \\
\hline PG0302 [NP 904618] & Hypothetical protein & PGI482 [NP 905628] & Conjugative transposon protein $\mathrm{TraF}$ \\
\hline PG0330 [NP 904645] & $\begin{array}{l}\text { DNA-binding protein, histone-like family; } \\
\text { smart004II, BHL }\end{array}$ & PGI483 [NP 905629] & Conjugative transposon protein $\mathrm{TraE}$ \\
\hline PG0555 [NP 904845] & DNA-binding protein, histone-like family & PGI488 [NP 905634] & Hypothetical protein \\
\hline PG0829 [NP 905084] & Hypothetical protein & PGI494 [NP 905640] & Hypothetical protein \\
\hline PG0870 [NP 905।I8] $]^{*}$ & Hypothetical protein & PG2040 [NP 906106] & DNA-binding protein, histone-like family \\
\hline PG0875 [NP 905।23] & $\begin{array}{c}\text { TnpA; DNA replication, recombination \& } \\
\text { repair, COG2452 }\end{array}$ & PG2I27 [NP 906I83] & Hypothetical protein \\
\hline PGI 206 [NP 905397]c & Mobilizable transposon, tnpC protein & BFI773 [YP 099054] ${ }^{*}$ & $\begin{array}{l}\text { Probable truncated integrase; cd0 I I85, } \\
\text { INT_Tn4399 }\end{array}$ \\
\hline
\end{tabular}

Missing in Porphyromonas gingivalis W83

\begin{tabular}{|c|c|c|c|}
\hline BF0I 27 [YP 0974I0] & TraB & BFI727 [무 099008] & $\begin{array}{l}\text { Putative outer membrane protein maybe } \\
\text { involved in nutrient binding }\end{array}$ \\
\hline BF0I36 [YP 0974I9] & $\begin{array}{l}\text { Tetracycline resistance element mobilization: } \\
\text { RteC }\end{array}$ & $\mathrm{BFI} 860$ [YP $099 \mid 42]$ & Hypothetical protein \\
\hline BF0I 46 [YP 097429] & Hypothetical protein & BFI926 [YP 211559] & Hypothetical protein \\
\hline BF0319 [YP 097602] $]^{*}$ & Putative exported protein & $\mathrm{BF} 2130$ [YP 0994II] & Hypothetical protein \\
\hline BF0342 [YP 097625$]$ & Putative exported protein & BF22 I4 [YP 099495] & Hypothetical protein \\
\hline BFI067 [YP 09835I] & Hypothetical protein & BF3 I 64 [YP 100443$]$ & Putative lipoprotein \\
\hline BFI422 [YP 098707] & Hypothetical protein & BF4258 [ [ & Hypothetical protein \\
\hline BFI567 [YP 09885I] & Hypothetical protein & & \\
\hline
\end{tabular}

The first five proteins in this table (viz. PG0336, PG 1302, PG 1537, PG 1626, PG2030) are present in all Bacteroidales and Flavobacteriales species listed in Table I; The other proteins are present in many of the Bacteroidales and Flavobacteriales species.

*Also present in C. phaeobacteroides.

The following proteins are homologous to each other: PG0330, PG0555, PG I276, PG I389, PG2040; PG0829, PG I444, PG I488; PG I25I, PG I479; BFI422, BFI860; BFI926, BF4258. 
Table 4: Proteins Unique to the Bacteroidales Order

\begin{tabular}{|c|c|c|c|}
\hline $\begin{array}{l}\text { Genome ID No. } \\
\text { [Accession No.] }\end{array}$ & Possible/Predicted Function & $\begin{array}{l}\text { Genome ID No. } \\
\text { [Accession No.] }\end{array}$ & Possible/Predicted Function \\
\hline PG0018 [NP 904375] $]^{\times}$ & hypothetical protein & PGII33 [NP 90534I] & conserved hypothetical protein \\
\hline PG0082 [NP 90443I] $]^{+}$ & putative exported protein & PGII39 [NP 905347] & $\begin{array}{l}\text { conserved hypothetical protein; } \\
\text { cd02966, Tlp_A_like_family }\end{array}$ \\
\hline PG0I25 [NP 904468] & conserved hypothetical protein & PGI 214 [NP 905405] & hypothetical protein \\
\hline PG0179 [NP 904515$]^{+}$ & putative exported protein & PGI30I [NP 905475] ${ }^{+}$ & conserved hypothetical protein \\
\hline PG0I88 [NP 904523] $]^{x}$ & lipoprotein, putative & PGI333 [NP 905502] ${ }^{x}$ & putative exported protein \\
\hline PG0216 [NP 904548 $]^{+}$ & conserved hypothetical exported protein & PGI352 [NP 9055I7] & putative conserved hypothetical protein \\
\hline PG0217 [NP 904549 $]^{+}$ & cons. hypothetical exported protein & PGI388 [NP 905550] $]^{+}$ & conserved hypothetical protein \\
\hline PG0218 [NP 904550] ${ }^{+}$ & conserved hypothetical exported protein & PGI44I [NP 905593] ${ }^{x}$ & $\begin{array}{l}\text { lysozyme-related protein; cd } 00737 \text {, } \\
\text { endolysin_autolysin; COG3772, phage- } \\
\text { related lysozyme }\end{array}$ \\
\hline PG0246 [NP 904573 $]^{+}$ & putative DNA-binding protein & PGI442 [NP 905594] & TraB \\
\hline PG03 I 2 [NP 904628 $]^{+}$ & putative transmembrane protein & PGI458 [NP 905606 $]^{\times}$ & hypothetical protein \\
\hline PG0326 [NP 90464I] & $\begin{array}{l}\text { hypoth; COG } 3637, \text { Opacity protein \& } \\
\text { related surface antigens }\end{array}$ & PGI473 [NP 905619] ${ }^{+}$ & conjugative transposon protein $\mathrm{TraQ}$ \\
\hline PG0366 [NP 904677] $]^{+\#}$ & hypothetical protein & PGI62I [NP 905750] & conserved hypothetical exported protein \\
\hline PG0434 [NP 904735 $]^{+}$ & putative transmembrane protein & PGI757 [NP 905859 $]^{\times}$ & hypothetical protein \\
\hline PG054I [NP 904834] ${ }^{+}$ & conserved hypothetical protein & PGI88I [NP 905968] ${ }^{+}$ & putative lipoprotein \\
\hline PG0574 [NP 904862] & hypothetical protein & PGI889 [NP 905974 $]^{x}$ & hypothetical protein \\
\hline PG07I7 [NP 904988 $]^{+}$ & lipoprotein, putative & PGI945 [NP 906027] ${ }^{+}$ & conserved hypothetical protein \\
\hline PG078I [ [NP 905043 $]^{+}$ & putative membrane protein & PG2006 [NP 906077] ${ }^{+}$ & $\begin{array}{c}\text { conserved hypothetical membrane } \\
\text { protein }\end{array}$ \\
\hline PG0816 [NP 905074 $]^{\times}$ & hypothetical protein & PG2079 [NP 906|4I] & conserved hypothetical protein \\
\hline PG083I [NP 905085] & Cons. protein maybe related to TraB & PG2083 [NP 906/45] ${ }^{+}$ & conserved hypothetical protein \\
\hline PG0843 [NP 905095] $]^{x}$ & conserved hypothetical protein & PG2116 [NP 906174] $]^{x}$ & transposase \\
\hline PG085I [NP 905I0I] & Toprim domain protein & $P G 2130[$ [NP 906186] & Fim X \\
\hline PG0910 [NP 905I50] & FHA domain protein, cd00060 & PG2131 [NP 906187] ${ }^{+}$ & 60 kDa protein; OmpA, COG2885.2 \\
\hline PG0937 [NP 905|72] & putative exported protein & PG2133 [NP 906189] $]^{x}$ & lipoprotein, putative \\
\hline PG096I [NP 905192] $]^{+}$ & conserved hypothetical protein & PG2149 [NP 906203] & putative conserved exported protein \\
\hline PGI050 [NP 905267 $]^{x}$ & putative lipoprotein & PG2168 [NP 906219$]^{+}$ & FimX \\
\hline PGII25 [NP 905334] ${ }^{+}$ & conserved hypothetical protein & PG2224 [NP 906265 $]^{\mathrm{x}}$ & hypothetical protein \\
\hline
\end{tabular}

All significant hits for these proteins are observed from the following Bacteroidales species, for which sequence information is available in the NCBI or TIGR microbial sequence database. P. gingivalis W83, B. fragilis NCTC 9343, B. fragilis YCH46, B. thetaiotaomicron VPI-5482, Prevotella intermedia 17, P. ruminicola 23. Unless noted below, these proteins are present in all of the above-mentioned species. Of these proteins, the following are homologous to each other: PG0179, PG2 I33; PG0217, PG0218; PG08I6, PGI458; PG083I, PGI442; PG2I30, PG2I68.

+Not found at present in either I or both Prevotella species.

$\times$ Missing in one of the Bacteroides species as well as Prevotella species.

\#Also present was $C$. phaeobacteroides BSI.

conserved hypothetical protein, PG1139, which shows slight but significant similarity to the conserved domain in the TlpA-like family, responsible for cytochrome maturation. One of the proteins PG0366 also had a significant hit from C. phaeobacteroides, which could be due to LGT [64]. There are seven proteins in Table 4 (PG0216PG0218, PG1441-PG1442, PG2130-PG2131) that are present in clusters of two or three, suggesting that they could form functional units. Further, a number of proteins in this table (viz. PG0179, PG2133; PG0217, PG0218; PG0816, PG1458; PG0831, PG1442; PG2130, PG2168) are homologous to each other, indicating that they resulted from gene duplication events.

The Bacteroides genus contains three fully sequenced genomes corresponding to B. thetaiotaomicron VPI-5482 and B. fragilis strains NCTC 9343 and YCH46. The blast searches on $B$. fragilis YCH46 genome have identified 185 proteins that are mainly specific for these species (Additional file 2) and their homologs are not found in P. gingivalis. For 10 of these proteins, significant similarity was also observed for at least one of the two Prevotella species, suggesting that within the order Bacteriodales, species from the Bacteroides and Prevotella genera may be more closely related to each other in comparison to $P$. gingivalis. Most of these proteins are of unknown functions, however, some have been annotated as transmembrane or lipoproteins. Thirty-nine of these proteins are present in clusters of two to four in the genome indicating that they could be involved in related functions. A number of proteins in this table are homologous to each other indicating that they have likely resulted from gene duplication events. 
Proteins that are specific for the order Flavobacteriales

The complete genome of the first flavobacteria species viz.G. forsetii KT0803 became available very recently [59]. However, sequence information for a large number of other Flavobacteriales species, whose genomes are being sequenced (see Table 1), is available in the NCBI database. Our blastp and PSI-blast searches on different ORFs in the $G$. forsetii genome have identified 38 proteins that are uniquely present in virtually all of the Flavobacteriales species (Table 5). Twenty-six of these proteins are present in all Flavobacteriales species listed in Table 1, whereas the remaining 12 are missing in only one of the species. An additional group of 146 proteins are also specific for the Flavobacteriales, but they are missing in some flavobacteria species or limited to only a small numbers of flavobacteria (Additional file 3). Because the genomes for most of the Flavobacteriales species are not complete at the present time, these proteins were not separated into different groups.

\section{Proteins that are unique for the Chlorobi Phylum}

The genomes of three Chlorobi species viz. C. luteolum DSM 273,C. tepidum TLS, and C. chlorochromatii CaD3, have been fully sequenced. Our blast analyses on the $C$. tepidum and C. luteolum genomes have identified 51 proteins that are uniquely shared by species from this phylum (Table 6). In addition to the 3 completely sequenced genomes, homologs of these proteins are also present in six others Chlorobi species (see Table 1), for which sequence information is available in the NCBI database. The genes for these proteins likely originated in a common ancestor of various Chlorobi species, which form a distinct, strongly supported, clade in phylogenetic trees (see Figures 1 and 2). The vast majority of these proteins are of hypothetical or unknown functions. However, 5 of them are indicated to be involved in functions related to photosynthesis. Of these, Plut_0264 and Plut_0265 are clustered in the genome and they correspond to chlorosome envelope proteins $\mathrm{C}$ and $\mathrm{A}$, respectively. The protein Plut_1500, which is indicated as bacteriochlorophyll A protein, corresponds to the FMO protein that is involved in the attachment of chlorosomes to the cytoplasmic membrane [34]. The other two photosynthesis-related proteins, Plut_0620 and Plut_1628, are annotated as photosystem P840 reaction centre protein PscD and the photosystem P840 reaction centre cytochrome c-551, respectively [24,32]. Three additional chlorobi-specific proteins, Plut_1714-Plut_1716, are clustered together in

Table 5: Proteins that are Specific for Species from the Flavobacteriales Order

\begin{tabular}{|c|c|c|c|}
\hline $\begin{array}{l}\text { orf No. } \\
\text { [Accession No.] }\end{array}$ & Possible/Predicted Function & $\begin{array}{l}\text { Genome ID No. } \\
\text { [Accession No.] }\end{array}$ & Possible/Predicted Function \\
\hline orf89 $[\underline{C A L 65078}]^{b}$ & membrane protein & $\operatorname{orfl} 826[$ CAL668I2] & hypothetical protein \\
\hline orf92 [CAL6508I] & secreted protein & orfl 872 [CAL66858] & hypothetical protein \\
\hline orfl07 [CAL65096] & membrane protein & orf2280 [CAL67264]c & hypothetical protein \\
\hline orfl I 0 [CAL65099] & conserved hypothetical protein & orf2667 [CAL6765I] & conserved hypothetical protein \\
\hline orfl91 [CAL65|80] & membrane or secreted protein & orf2698 [CAL67682] & secreted protein \\
\hline orf403 [CAL65392] $]^{b}$ & hypothetical protein & $\operatorname{orf} 2700$ [CAL67684] & hypothetical protein \\
\hline orf509 [CAL65498 $]^{c}$ & hypothetical protein & orf27 18 [CAL67702] & hypothetical protein \\
\hline orf6 I 2 [CAL65599 $]^{b}$ & secreted protein & orf273I [CAL677I5] ${ }^{\mathrm{b}}$ & secreted protein \\
\hline orf983 [CAL65970] ${ }^{\mathrm{a}}$ & hypothetical protein & $\operatorname{orf} 2756$ [CAL67740] & secreted protein \\
\hline orf995 [CAL65982] & $\begin{array}{c}\text { phospholipid/glycerol } \\
\text { acyltransferase; smart00563, PlsC }\end{array}$ & orf2825 [CAL67809] & secreted protein \\
\hline orf998 [CAL65985] & membrane protein & orf2844 [CAL67828] & membrane protein \\
\hline orfl059 [CAL66046] & membrane protein & orf2917 [CAL67899] & secreted protein \\
\hline orfl1078 [CAL66065 $]^{\mathrm{a}}$ & membrane or secreted protein & orf2939 [CAL6792I] & hypothetical; COGI577, ERGI 2 \\
\hline orfl453 [CAL66440] & secreted protein & orf3043 [CAL68025] & hypothetical protein \\
\hline $\operatorname{orfl} 469[\underline{C A L 66456}]^{\mathrm{a}}$ & secreted protein & orf3076 [CAL68058] $]^{\mathrm{C}}$ & hypothetical protein \\
\hline orfl 555 [CAL66542] & secreted protein & orf3240 [CAL68223] & membrane protein \\
\hline orfl618 [CAL66605 $^{\mathrm{d}}$ & secreted protein & $\operatorname{orf3266}[\underline{\mathrm{CAL} 68249}]^{\mathrm{a}}$ & conserved hypothetical protein \\
\hline orf I766 [CAL66752] & hypothetical protein & orf33 I3 [CAL68296] & hypothetical protein \\
\hline orf I776 [CAL66762] & hypothetical protein & orf350I [CAL68484] & conserved hypothetical protein \\
\hline
\end{tabular}

Unless otherwise indicated, all significant hits for the proteins listed in this table are from the following Flavobacteriales species, for which sequence information is presently available. G. forestii KT0803, F. bacterium BBFL7, F. bacterium HTCC2 I 70, F. johnsoniae UW I 0 I, Flavobacterium sp. MED2 I 7 , Cellulophaga sp. MED 134, C. atlanticus HTCC2559, P. irgensii 23-P, P. torquis ATCC 700755, R. biformata HTCC250I, Tenacibaculum sp. MED I52. The proteins are present in all of these species except as noted below:

aMissing in Polaribacter irgensii 23-P

bMissing in Flavobacterium johnsoniae UWIOI

cMissing in Flavobacteria bacterium BBFL7

dMissing in Psychroflexus torquis ATCC 700755

eMissing in Robiginitalea biformata HTCC250I 
the genome indicating that they may form a functional unit [61]. There are 65 additional proteins that are also specific for the Chlorobi species (Additional file 4). However, unlike the proteins in Table 6 , these proteins are missing in a number of the Chlorobi species and their species distribution does not show any clear pattern and these could involve gene loss or LGTs [65]. However, the first 8 proteins listed in this additional file (viz. Plut_0107, Plut_0759, Plut_0762, Plut_0981, Plut_0985, Plut_1092, Plut_1145, Plut_1858) are only found in C. luteolum and $C$. phaeovibrioides. These two species form a strongly supported clade in various phylogenetic trees (Figs. 1 and 2) and a specific relationship between them is further supported by the unique presence of these shared proteins. For one of the proteins in this table, Plut_1345, a significant hit is also observed from C. hutchinsonii, which could be due to LGT $[64,65]$.

In addition to the proteins that are uniquely found in various Chlorobi species, we have also identified two large conserved inserts in two widely distributed proteins that are distinctive characteristics of the Chlorobi phylum. The first of these signatures is a 28 aa insert in the DNA polymerase III alpha subunit encoded by the dnaE gene that is required for chromosomal replication in bacteria [66]. The large insert in DnaE is present in all of the Chlorobi homologs but it is not found in any other species (Fig. 3 ). A smaller insert of 3-4 aa is probably also present in this regions in some Bacteroidales species, but based on their different sizes and sequence characteristics, these inserts are of independent origin. The other Chlorobi-specific signature consists of a 12-14 aa insert in alanyl-tRNA synthetase (Fig. 4), which plays an essential role in protein synthesis. This insert is again present in all Chlorobi homologs but not found in any other species indicating that it provides a reliable molecular marker for this group.

Proteins that are uniquely shared by the Bacteroidetes and Chlorobi species

The Bacteroidetes and Chlorobi species generally branch very close to each other in phylogenetic trees [27-30]. However, there are very few characteristics known that are

Table 6: Proteins that are Specific for the Chlorobi Species

$\begin{array}{llll}\begin{array}{l}\text { Genome ID No. } \\ \text { [Accession No.] }\end{array} & \text { Possible/Predicted Function } & \begin{array}{l}\text { Genome ID No. } \\ \text { [Accession No.] }\end{array} & \text { Possible/Predicted Function }\end{array}$

Plut_0059 [YP 373992]

Plut_0074 [YP 374007]

Plut_0I II [YP 374044]

Plut_0I45 [YP_374078]

Plut_0160 [YP 374093]

Plut_0264 [YP 374195]

Plut_0265 [YP 374196]

Plut_0278 [YP 374209]

Plut_0282 [YP 374213]

Plut_0295 [YP 374226]

Plut_0325 [YP 374256 ]

Plut_0409 [YP 374340]

Plut_0422 [YP 374353]

Plut_0489[YP 374420$]$

Plut_0499[YP 374430]

Plut_0540 [YP 374467]

Plut_0572[yP 374498]

Plut_0620 [YP 374546]

Plut_0666 [YP 374587]

Plut_07/3 [YP 374634]

Plut_0779[YP 374695]

Plut_0950 [YP 374855]

Plut_1012 [YP 374917]

Plut_II $95\left[\begin{array}{ll}Y P & 375100\end{array}\right]$

Plut_1217 [YP 375I22]

Plut_I223 [YP 375।28]
Hypothetical protein orfCR

Hypothetical protein

Hypothetical protein

Hypothetical protein

chlorosome envelope protein $C$

chlorosome envelope protein $\mathrm{A}$;

Bac_chlorC, pfam02043

Hypothetical protein

Hypothetical protein

Hypothetical protein

Hypothetical protein

Hypothetical protein

Hypothetical protein

Hypothetical protein

Hypothetical protein

Hypothetical protein

Hypothetical protein

Photosystem $\mathrm{P} 840$ reaction center protein PscD

Hypothetical protein

Hypothetical protein

Hypothetical protein

Hypothetical protein

Hypothetical protein

Hypothetical protein

Hypothetical protein

Hypothetical protein
Plut_1225 [YP 375|30]

Plut_I 238 [YP 375।43]

Plut_I 332 [YP 375234]

Plut_I 409 [YP_3753II]

Plut_I 465 [YP 375367]

Plut_I469[YP 37537I]

Plut_I49I [YP 375393]

Plut_I500 [YP 375402]

Plut_I5I7 [YP 3754I7]

Plut_1608 [yP 375505]

Plut_I625 [YP 375522]

Plut_I 628 [

Plut_1682 [YP 375579]

Plut_I7 I4 [YP 3756II]

Plut_I7I5 [YP 375612]

Plut_1716 [YP 375613]

Plut_I 725 [YP 375622]

Plut_I 742 [YP 375639]

Plut_I 743 [YP 375640]

Plut_I 746 [YP 375643]

Plut_1933 [YP 375818]

Plut_2003 [YP 375888]

Plut_204I [YP 375926]

Plut_2100[YP 375985]

Plut_21 17 [YP 376002]
Hypothetical protein

Hypothetical protein TPR repeat

Hypothetical protein Hypothetical protein

Hypothetical protein

Hypothetical protein

FMO, BchlA protein

Hypothetical protein Srm

Hypothetical protein

Photosystem $P 840$ reaction center cytochrome c-55I

Hypothetical protein

Hypothetical protein

Hypothetical protein

Hypothetical protein

Hypothetical protein

Hypothetical protein

Hypothetical protein

Hypothetical protein

Hypothetical protein orfCR

Hypothetical protein

Hypothetical protein

Hypothetical protein

All significant Blast hits for these proteins are observed only from the following Chlorobi species for which sequence information is presently available: C. luteolum DSM 273, C. tepidum TLS, C. chlorochromatii CaD3, C. limicola DSM 245, C. phaeobacteroides BSI, C. phaeobacteroides DSM 266, C. clathratiforme BU-I, P. aestuarii DSM 27 I and C. phaeovibrioides DSM 265. Of these proteins, the following proteins are homologous to each other:Plut_0059, Plut_I 49I; Plut_0074, Plut_2003. 


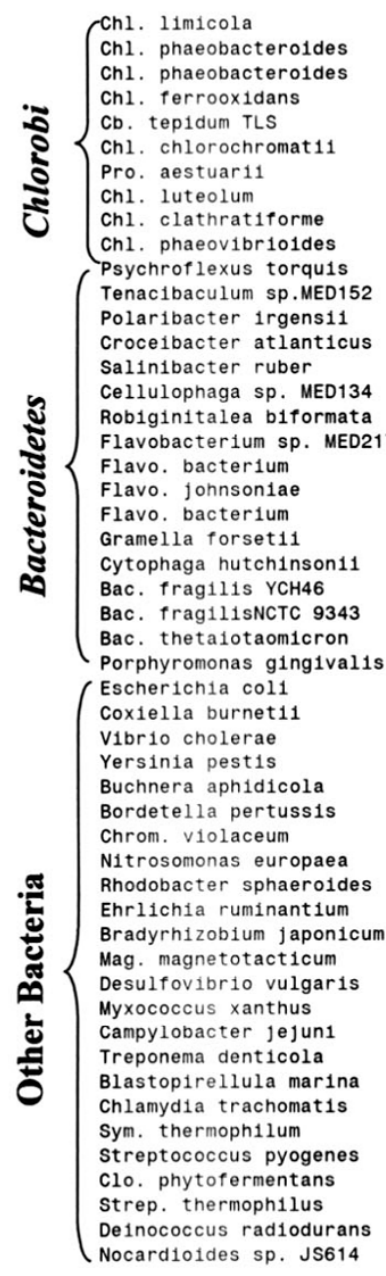

\begin{tabular}{l}
67918197 \\
67935336 \\
67939104 \\
110597394 \\
21673669 \\
78188863 \\
68552475 \\
78187124 \\
68549240 \\
71480862 \\
91220500 \\
86135389 \\
88802679 \\
83856344 \\
83814834 \\
86130781 \\
88804031 \\
86141808 \\
88711234 \\
90588233 \\
89890044 \\
117579503 \\
110636521 \\
53712001 \\
60680202 \\
29347640 \\
34539911 \\
110640403 \\
95926693 \\
15642243 \\
16121359 \\
15616854 \\
33593326 \\
34496366 \\
30249925 \\
83373380 \\
57238919 \\
27379977 \\
46203696 \\
46579764 \\
108762214 \\
57237020 \\
42528286 \\
87306887 \\
76789282 \\
51891797 \\
15675237 \\
106886892 \\
55821207 \\
15805534 \\
71369125 \\
\hline
\end{tabular}

502

EGRARNVSMHAGAVVITDGPLEEQVPLY

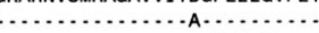

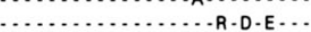

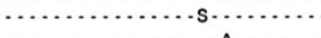

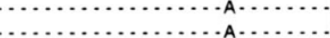

........................

C....................

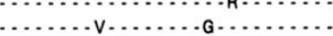

-GI - IGK.-G.MAP-S.SDFS-I

-SV - -TGI - . CG - I - .P.DITNY - -VA

-SV . .TGI ...CG - I ..P.DITNY ..VA

-SV - - TGV - - CG - I - . PDDISNF - - IA

-SV-HTGV - -AG-I - AP-EISDY - -VS

-.SV . .TGI -..CG - I -.PDDITNF - .VA

- .SL - . TGI - . CG - I . . PDDITNF . . VA

- SV - -TGI - - CG - I - - PDDITNF - -VS

-SV - -TGI - . CG - I - - PDDITKF - -VA

- SM - - TGI - C CG - I - - PSDITNY - V VT

-SV - - TGV -.CG - I - . PA - - TNF - -VA

.SV . .TGI ..CG - I..P.D.DITNY ..VS

SV - GTOI - AGI I APKD YDII - VF

-

-NV-GTGV - - CGTI - CRDDITDW - V V

- NV - GTGV - - CGTI - CRDDITDW - - VS

- NV - GTGV - - CGTI - CRDDITDW - - VS

-NV - - TGV - . CGII - GKTDISDV - -VS

. .VT . . AGK ...G....APTKITDFA ...

LT -AGK - A APTK TDF ....

CT -AGK - G SPTAITDFA I

CT . AGK....... SPTAITDFA-I

VT. . AGK.........APTKITDFA..

-TN - IGK ... G...SPTKITDFC...

-LT-SIG -...-G-L-AP-K-TDFC...

-DLT-GIG -...G-L-AP-R - TDFC...

-LT ...G....G-L-AP-KITDFC-V

-LL..A-T..AG ...G-R.-D-L...

LY $H$ - I - AGI $C$ - AK - L

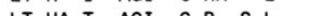

-LT-Ha-T. -AGI - C-R.-S.L...

-LH-HA-T..AG ...G-R ........

- LS-HA-T - .AG -..S-K-MS-YL ...

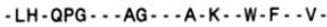

- LN - - AG - . AG - . S SNES - WKKT - . F

-.N - - S - L . -AGI - . GKTA - TDY....

L

MP.

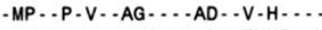

- NP - QT - I - AGI - MS - DA - TNHI - - K

-LP. HT ....AG -..SSA-AD-Y...S

- QP - QT - I - - AGI - MS - DD - TNHI - - K

- LT - HA - V . -AG . . . GREE - TNL . V VM

- Q QI - - WGV - - AG - IMSSE - . INV - . IM

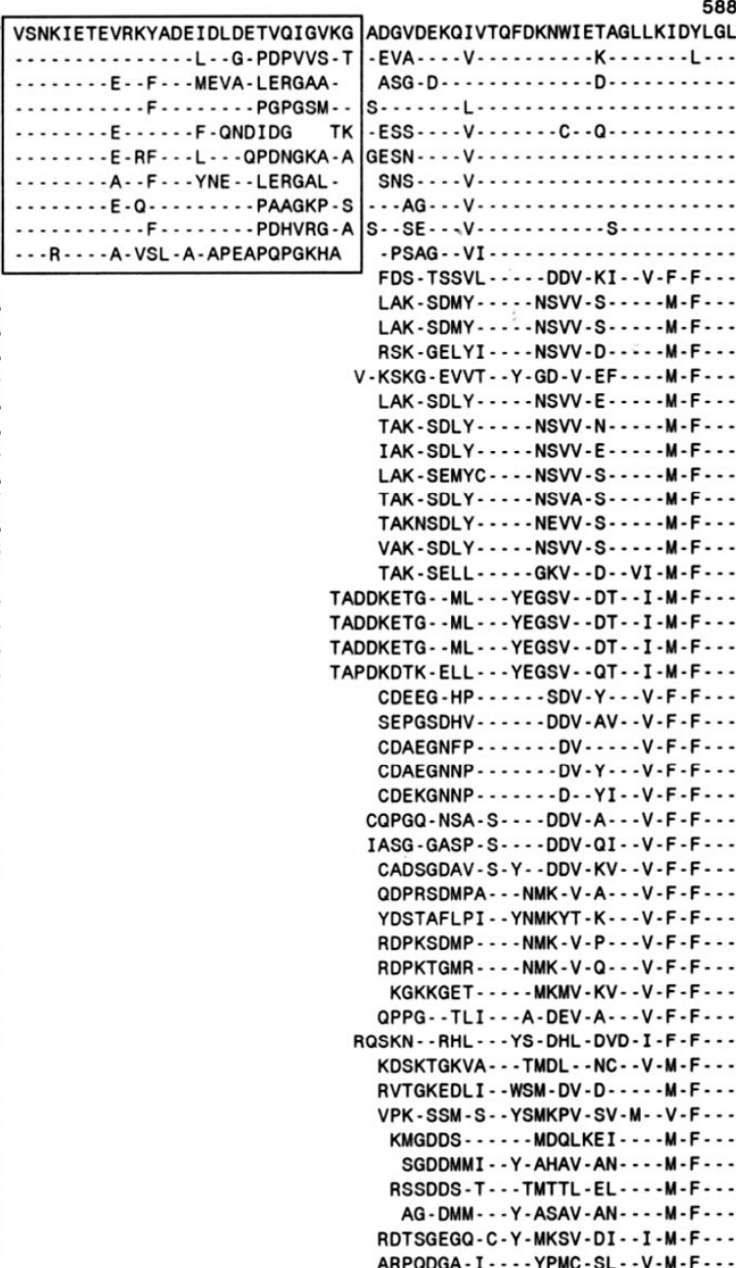

ARPODGA.I.....YPMC-SL..V-M.F...

\section{Figure 3}

Partial sequence alignments of the DnaE protein showing a large insert of about 28 aa that is uniquely present in Chlorobi homologs. The dashes (-) denote identity with the amino acid on the top line. Except for the Chlorobi species, this insert is not found in any other organism. Sequence information for only representative species from other groups of bacteria is shown. Abbreviations in the species names are: Bac., Bacteroides; Cb., Chlorobaculum; Chl., Chlorobium; Chrom., Chromobacterium; Clo., Clostridium; Pro., Prosthecochloris; Sym., Symbiobacterium; Flavo., Flavobacterium; Strep., Streptococcus.

uniquely shared by species from these two phyla. Our analysis has identified 3 proteins (PG0081, PG0649 and PG2432 in Table 7) that are uniquely found in virtually all of the fully as well as partially sequenced Bacteroidetes and Chlorobi genomes. These results are significant because Bacteroidetes or Chlorobi species do not share any protein in common with different species from any other group of bacteria. Of these proteins, the protein PG0081 is also found in Fibrobacter succinogenes. A close and specific relationship of F. succinogenes to the Bacteroidetes and Chlorobi groups was strongly suggested by our earlier work based on conserved indels in different proteins [30]. This inference is reinforced by the unique presence of this protein in these different groups. The absence of the protein PG0649, which is present in all other Bacteroidetes and Chlorobi species, in $S$. ruber, is probably due to gene loss. Three other proteins, PG1818, PG1977 and BF2465 although they appear unique to the Bacteriodales and Chlorobi, their homologs are not detected in most Flavobacteria including $G$. forsetii. It is likely that the genes for these proteins also evolved in a common ancestor of the Bacteroidetes and Chlorobi phyla followed by gene losses in particular Bacteroidetes lineages. All of these proteins are of unknown functions except PG1818, which is annotated as a putative transmembrane protein with significant similarity to the conserved domain of the ResB-like family. 


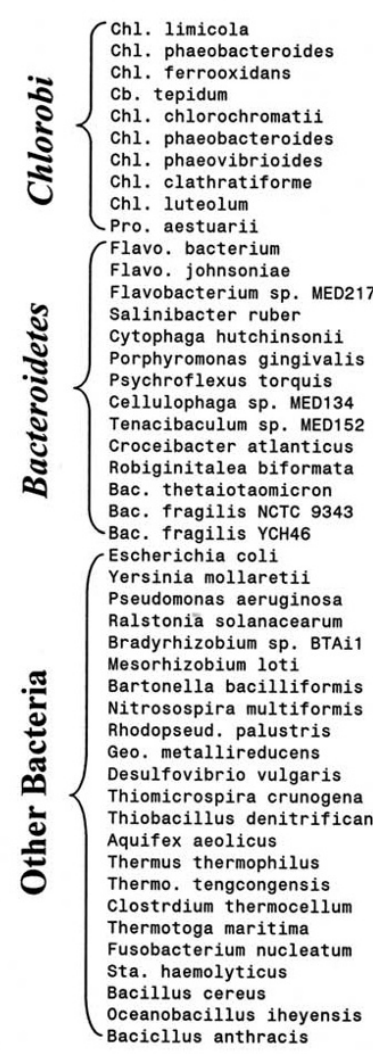

489

\begin{tabular}{|c|c|c|c|}
\hline & TPFYAESGGQSGDCGWIETAEYRLKVSDTRKDGDAIVHVVTEAHDTARDSAIDPADVSFD & DRAN & RQGTERNHTATHLLHAALRRILGQHVQQKGSF \\
\hline 67935031 & 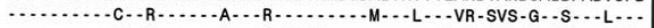 & $-\mathrm{SD}$ & \\
\hline 110597674 & 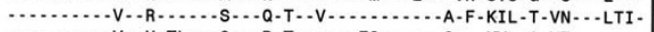 & E-Q-SAE & $\because D \cdots \cdots$ \\
\hline 21673007 & $\cdots$ & - -VVSVK-A...DR & 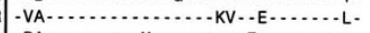 \\
\hline 78188347 & 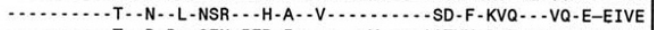 & QE.-VA-...H-TA- & 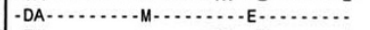 \\
\hline 67939503 & 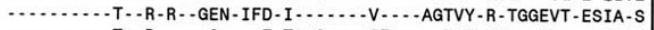 & QAVQVQ-Q--KET & 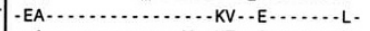 \\
\hline 71482352 & 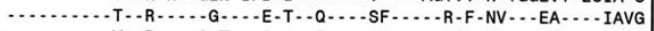 & PGRVH -.....KL & \\
\hline 68550731 & 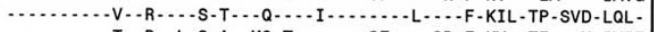 & EKE-SAE.......HL & 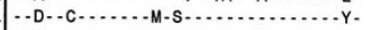 \\
\hline 78187794 & 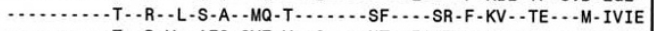 & EATPVD -...E-IL & 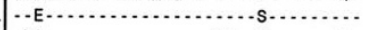 \\
\hline 68552548 & 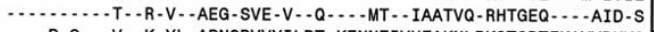 & ASV-vav......QS & -LA $\cdots+\ldots+\ldots$ \\
\hline 88713452 & $\cdots-P-G-\cdots-V-K-Y L-A P N G D V V Y I L D T-K E N N E I V H F A K N L P K S T S D T F K A V V D K K Q$ & & $\because R-A A-\cdots \cdots \cdots \cdot Q \cdots E V \cdots N-E$ \\
\hline 90590374 & $\cdots-G-\cdots-T--K-Y L$-AQNGDIVYIIDT-KENNQTIHL-QSLPENITGTFNAVVDANQ & & -AK-SS-.S-...-QG--K-..T-IE \\
\hline 86142096 & .....-G-V-K-YL-A-NGDVVYITDT - KENNLIIHLSKNLPKNLNETFTAVVDAKQ & & $-H R-Q A-. S \cdots \cdots \cdot Q-\cdots A V-\cdot T-\cdot E$ \\
\hline 83814294 & $\cdots \cdots-A \cdots V--T-T L R F G D E S V Q-L \cdots$ - QRE-ER-A-T-DTLPEPLDGPVEAAV-AERR & & NHIRAH -.....-M-V - - ET . D ... \\
\hline 110637850 & $\cdots \ldots$ A - T-TLVQGDKKI - -LN-V-ENNL-I - ITEQLPADLKAPVDCKVN-LQR & & 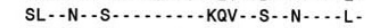 \\
\hline 34540951 & ....-M-.-V--S-QLIDESGVAYDIFDT-RENNLSVHLMKKLPESTTDTFVARINQDK & & 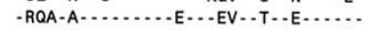 \\
\hline 91217166 & 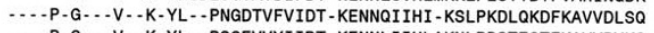 & & 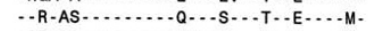 \\
\hline 86132032 & -...P-G-..V--K-YL-.PSGEVVYIIDT-KENNLIIHLAKNLPRSTEGTFKAVVDVKQ & & $-S R-A A \cdots \cdots+C Q G-K \cdots-T \cdot E-$ \\
\hline 86134548 & ....P-G-..V--K-YL-DTHGDVVYILDT-KENNVIIHFAKNLPQNL-ANFKAVVDEKQ & & 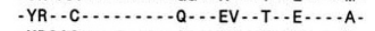 \\
\hline 83856372 & .....-G-V-V-K-YL-SPDGDVVYIVDT - KENNL-VHF-KNLPKHPEATFKAVVD-KQ & & 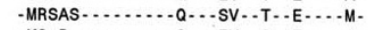 \\
\hline 88805022 & ....P-G-..-V-.S-HL-GSGGAVTEILDTRKENNEILHI - ..-LPEDPGAEFL & & 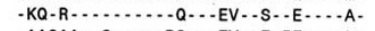 \\
\hline 29349403 & $\cdots \cdots+-\cdot-T$-VLVSEFETIE-I - K-ENNLPI - ITKKLPEHPEAPMMACV-TDKR & & AACAA-.S -....DS-..EV - E -IE. \\
\hline 60680248 & 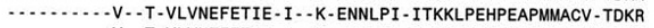 & & 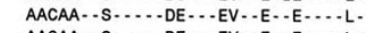 \\
\hline 53712054 & $\cdots \cdots+$ V - - T-VLVNEFETIE - I - - K-ENNLPI - ITKKLPEHPEAPMMACV - TDKR & & 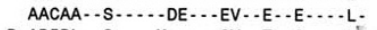 \\
\hline 110642817 & W.W. -V-VK-ELKG-NFSFA-E--Q-Y-Q--G-IGK & & 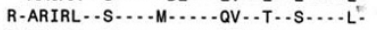 \\
\hline 77961320 & $\cdots \cdot G-\cdots-V--T$-ELKN-TATFA-A - Q-Y-Q--G-LGKLT-G-L-VNHSID-Q-DVT & & 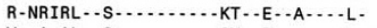 \\
\hline 94417996 & 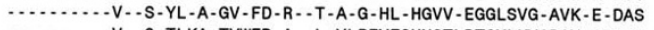 & & 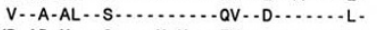 \\
\hline 83747684 & $\cdots . . .-V-Q-T L K A-T V W F D-A-$ - L-VLPEVFGHHGTLRTGVLKVGDAV-AEVDA & & VR-AR-M- - S - - - M-K- - EV - - G- \\
\hline 78698856 & -..-G-...-V--T-VMSGDGV-VRIT - - Q-KAGDLFV & & GR-SAIRA - -S - . I - E $\cdots$ \\
\hline 13470354 & $\cdots-G-\cdots-M-$-T-I-SGEGFSIEI $\cdots Q-$-KA-GLFV & & 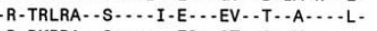 \\
\hline 2500957 & -..-G-...-V--S-I-SG-NFIFE-H- - Q-K--NVFIHIG-IK & & -R-RKIRA.-S......ES- - QT-.S.. \\
\hline 82701157 & ..........-V-S-ELLA-NGTFA-A- - Q-IQADVFGHKGLL & & $-A-A R-\cdots .-S V \cdots M-K \cdots E V--H \cdots$ \\
\hline 91976212 & $\ldots . . . .-$ V - - T-VLTGEGV-FR-T - -L-KAGDLFVHFGTVEEGTVKPEAAL-LEVDH & & 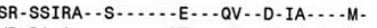 \\
\hline 7822 & ‥G-A...A-T-T-S-GSAHVR-TG-IRPYPDLIVHRGTVVEGTIKTGEACDLKVAS & & 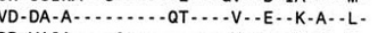 \\
\hline 114847969 & $\cdots$ GA $\cdots$ - I - T-ASPSGKVR -V - - I - PSPEL -VHHV - -VEGDILLDQEVDLTVTE & & 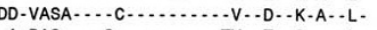 \\
\hline 78485931 & .......-Q-Q-SLTEGMNSFH-DNCQ-Q-A-F & & 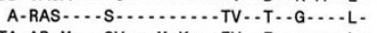 \\
\hline 74316571 & $\cdots . . .-$ V - R-TLQSKQGAFE-E - L-IQAQVFGHHGVVKTGSLAVC & & TA-AR-M-..SV - - M-K- - EV - E E - \\
\hline 15606507 & 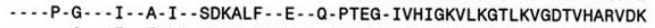 & & 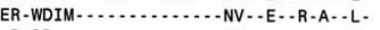 \\
\hline 55981800 & $\cdots \cdots$ G- - I - F-LLL-WPGG-AR-ET- $\cdots$-TERG-FLHKARVEEGVLRVGERVRA-VDP & & R-RD. \\
\hline 20807697 & N.....-V--S-V--EEDTLI - -N-CK-V-NKFI-IG-VERGLISVGD & & $-K-K E V \cdots D \cdots N-$ \\
\hline 67875597 & …..... - - - K-L--AEGA-V--L-CK-TN-GKYLHIG-IEEGTLRNGMEVKATIDK & & KR-MAIA - ...T T \\
\hline 156 & $\cdots \cdots-K \cdots$-VS-T-MV-WRDGKAL-EYVFEASEGVIVHRIKIL-GTLRRGQKVILRVDK & & $\cdots \cdot$ KKV - D D. \\
\hline 1970 & ........-V-Q-K-YSDNFAG--L-VQ-QK-IFI-T-KLEKGMPEENKTYKLE-DVV & & $K-L D-A K-\cdots . .-K-$ K - E-V-T. \\
\hline 70726302 & $\cdots . .-V \cdot$ VA-K-TVGNENFEIE-TEVT-APNC & & DE-KDIQK--S- \\
\hline & W......IA-R-YLLADGVKVL-K-VQ-APNC & & K--SSVVK- \\
\hline 2309 & 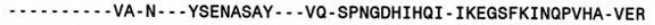 & & $-Q--K D V-\cdot S-.1$ \\
\hline 30264458 & - IA-R-CLLADGVKVL-K-VQ-APNGQNLF & & $-Q--K D V \cdots T \cdot-1$ \\
\hline
\end{tabular}

\section{Figure 4}

Partial sequence alignments of alanyl-tRNA synthetase showing a conserved insert of about I2-14 aa that is a distinctive characteristic of Chlorobi homologs and not found in other bacteria. The dashes (-) denote identity with the amino acid on the top line. Additional abbreviations: Geo., Geobacter; Sta., Staphylococcus; Thermo., Thermoanaerobacter.

\section{Discussion}

This work has identified a large number of proteins that are specific for Bacteroidetes and Chlorobi species at various taxonomic levels. Homologs exhibiting significant similarity to these proteins are not found in any other bacteria, except in a few isolated cases. Among the proteins that are specific for the Bacteroidetes, 27 proteins are specific for the entire phylum as their homologs are present in species from all three main orders within this phylum. Many other proteins are limited to various clades within the Bacteroidetes phylum. These include 41 proteins that are common to the Flavobacteriales and Bacteroidales orders; 53 and 38 proteins that are specific for the Bacteriodales and Flavobacteriales orders, respectively; and 185 proteins that are specific for the Bacteriodes genus. We have also identified 51 proteins that are specific for the Chlorobi species and 6 proteins that are uniquely shared by the Bacteroidetes and Chlorobi phyla. Two large conserved inserts in the DnaE and AlaRS proteins that are distinctive characteristics of the Chlorobi species were also discovered in this work. In addition, a deletion in ClpB protein that is mainly specific for the Bacteriodales, Flavobacteriales and Flexibacteraceae was also identified. In earlier work, a number of conserved inserts that are specific for either the Bacteroidetes phylum (viz. SecA and Gyrase B) or commonly shared by the Bacteroidetes and Chlorobi species were also described. Based upon their specificity for the Bacteroidetes and Chlorobi species, these molecular markers provide novel and more definitive means for identifying and circumscribing species from these groups.

The species distribution patterns of these signature proteins and conserved indels strongly suggest that they or the genes for them have evolved at various stages in the evolution of these bacteria (Fig. 5). However, subsequent to their evolution or introduction in these genes, these genomic characteristics are stably retained in various descendents of these lineages with minimal gene loss or LGTs, as has also been found in other related studies [37$41,44,67,68]$. The evolutionary relationship among the Bacteroidetes species as deduced from these signature proteins is in complete agreement with their branching pat- 
Table 7: Proteins that are Uniquely Shared by the Bacteroidetes and Chlorobi Species

\begin{tabular}{|c|c|c|c|c|c|c|}
\hline $\begin{array}{l}\text { Protein I.D. No. } \\
\text { [Accession No.] }\end{array}$ & $\begin{array}{c}\text { PG008I } \\
{[\mathrm{NP} 904430]}\end{array}$ & $\begin{array}{c}\text { PG0649 } \\
{[\text { NP 904929] }}\end{array}$ & $\begin{array}{c}\text { BF2432 } \\
\text { [YP 0997I5] }\end{array}$ & PGI8I8 [NP 9059|7] & $\begin{array}{c}\text { PGI977 } \\
{[N P \text { 90605I] }}\end{array}$ & $\begin{array}{c}\text { BF2465 } \\
\text { [YP 099748] }\end{array}$ \\
\hline $\begin{array}{l}\text { Length (aa) } \\
\text { Possible Function }\end{array}$ & $\begin{array}{l}725 \text { aa } \\
\text { Hypoth. }\end{array}$ & $\begin{array}{l}194 \text { aa } \\
\text { Hypoth. }\end{array}$ & $\begin{array}{c}1478 \\
\text { Hypoth. }\end{array}$ & $\begin{array}{l}238 \mathrm{aa} \\
\text { Putative transmembrane }\end{array}$ & $\begin{array}{l}668 \text { aa } \\
\text { Hypoth. }\end{array}$ & $\begin{array}{l}93 \text { aa } \\
\text { Hypoth. }\end{array}$ \\
\hline \multicolumn{7}{|l|}{ Bacteroidetes } \\
\hline P. gingivalis & $*$ & $*$ & $*$ & $*$ & $*$ & $*$ \\
\hline B. fragilis NCT & * & $*$ & * & * & $*$ & * \\
\hline B. fragilis $\mathrm{YCH}$ & * & $*$ & $*$ & * & $*$ & * \\
\hline B. thetaiotaomi. & $*$ & $*$ & $*$ & $*$ & $*$ & $*$ \\
\hline Prev. intermedia & $*$ & $*$ & $*$ & * & * & $*$ \\
\hline Prev. ruminicola & $*$ & $*$ & $*$ & & $*$ & * \\
\hline G. forestii & * & $*$ & $*$ & & & \\
\hline F. bacterium $\mathrm{BBF}$ & $*$ & $*$ & $*$ & & & * \\
\hline F. bacterium HTC & $*$ & $*$ & $*$ & & & \\
\hline F. johnsoniae & $*$ & $*$ & $*$ & & & \\
\hline Flavobacterium & $*$ & $*$ & $*$ & & & \\
\hline Cellulophaga & $*$ & $*$ & $*$ & & & \\
\hline C. atlanticus & * & $*$ & $*$ & & & \\
\hline Polibacter irgensii & $*$ & $*$ & $*$ & & & \\
\hline Psychro. torquis & * & * & $*$ & & & \\
\hline Rob. biformata & * & $*$ & & & & \\
\hline Tenacibaculum & $*$ & $*$ & $*$ & & & \\
\hline Cyto. hutchinsonii & * & $*$ & $*$ & & $*$ & * \\
\hline Salinibacter ruber & $*$ & & $*$ & & * & \\
\hline \multicolumn{7}{|l|}{ Chlorobi } \\
\hline Cb. tepidum & $*$ & $*$ & & * & $*$ & \\
\hline C. chlorochrom. & $*$ & $*$ & $*$ & $*$ & $*$ & $*$ \\
\hline C. luteolum & $*$ & $*$ & $*$ & $*$ & $*$ & $*$ \\
\hline C. limicola & * & * & $*$ & * & $*$ & \\
\hline C. phaeobac BSI & $*$ & * & $*$ & * & $*$ & \\
\hline C. phaeobac DSM & $*$ & $*$ & $*$ & $*$ & $*$ & \\
\hline C. clathratiforme & * & $*$ & $*$ & $*$ & $*$ & * \\
\hline Prosthec. aesturii & $*$ & $*$ & $*$ & * & * & $*$ \\
\hline C. phaeovibrioides & $*$ & $*$ & $*$ & $*$ & $*$ & \\
\hline
\end{tabular}

All significant blast hits for these proteins are from the indicated (marked by *) Bacteroidetes and Chlorobi species. For the protein PG008I, a homolog is also present in Fibrobacter succinogenes subsp. succinogenes $\mathbf{8 5}$ (identified by blast search against the partial sequence). The blank space indicates that no hit showing significant similarity was detected at the present time.

tern in phylogenetic trees (Figs. 1 and 2). The unique presence of several signature proteins as well as conserved indels in a number of essential proteins (viz. FtsK, UvrB and ATP synthase alpha subunit) by different Bacteroidetes and Chlorobi species provides compelling evidence that species from these two groups shared a common ancestor exclusive of all other bacteria. In earlier studies, a close relationship of Fiborbacteres to the Bacteroidetes and Chlorobi was also observed $[2,30]$. The species from all these three groups were found to contain large conserved indels in RNA polymerase $\beta$ ' subunit and serine hydroxymethyl transferase, that were not found in any other bacteria [30]. The species from these three groups also branched in the same position based on distribution profiles of signature sequences in a number of other proteins and in different phylogenetic trees $[30,69]$. The unique shared presence of the protein PG0081 by all sequenced Chlorobi and Bacteroidetes species as well as Fibrobacter succinogenes, provides further evidence that species from these three groups form a single superphylum and that they shared a common ancestor exclusive of all other bacteria [30].

This paper also reports phylogenetic analyses of Bacteroidetes and Chlorobi species based on a concatenated alignment of 12 highly conserved proteins. The branching order of various species in the trees obtained using different phylogenetic methods were in general very similar with the clades corresponding to the Chlorobi species and the Cytophaga-Flavobacteria-Bacteroides species, well resolved from each other with $100 \%$ bootstrap scores. The species corresponding to the two main groups within the Bacteroidetes phylum (viz. the Bacteriodales and Flavobacteriales orders) were also clearly resolved. However, in the trees constructed by traditional phylogenetic methods such as NJ, ML and MP, the phylogenetic placement of $S$. ruber was not resolved. In all of these trees, $S$. ruber 


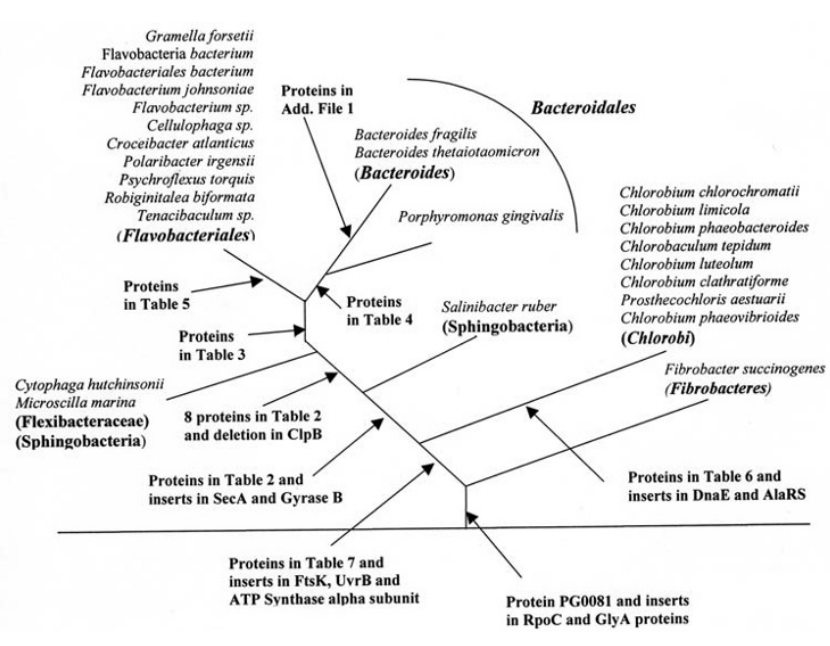

Figure 5

A summary diagram showing the evolutionary stages where different signature proteins and conserved indels that are specific for the Bacteroidetes and Chlorobi species have likely evolved or originated. Some of the conserved inserts that are specific for these groups or indicate their branching position relative to other bacterial phyla have been described in earlier work [30,43,69].

appeared either as a very deep branch of the Chlorobi clade (i.e. in NJ and ML trees) or as outgroup of both the Chlorobi and the $\mathrm{CFB}$ clades (MP tree). In contrast to these trees, when the same dataset was analyzed by means of the character compatibility or clique approach, S. ruber formed the deepest branch of the Bacteroidetes species and its specific association with this group was supported by 21 uniquely shared characters, indicating strongly that this affiliation was reliable [57]. These results provide evidence that the character compatibility approach, which removes all fast-evolving as well as homoplasic sites from a given dataset, provides a powerful means for obtaining correct topology in cases, such as that for S. ruber, whose phyletic affinity has proven difficult to establish by traditional phylogenetic methods [13,52,56,57].

The cellular functions of most of the Bacteroidetes or Chlorobi-specific proteins identified in the present work are not known. A few of the Chlorobi-specific proteins are involved in chlorosome- or photosynthesis-related functions, which is expected as Chlorobi is one of the few bacteria phyla that possesses photosynthetic ability $[22,31,32,34,70]$. A number of other proteins exhibit weak sequence similarity to conserved domains in certain other proteins, but considering that the overall sequence similarity is not significant, the actual functions of these proteins could be quite different. Therefore, an important task for the future is to determine the cellular functions of these Bacteroidetes or Chlorobi specific proteins. Likewise, it is also of much interest to determine the functional signif- icance of the conserved indels in SecA, Gyrase B and ClpB proteins that are distinctive characteristics of the Bacteroidetes [30], and of the inserts in DnaE and AlaRS proteins that are specific for the Chlorobi species. The retention of these signature proteins and conserved indels by all species from these groups strongly suggests that they are functionally important for these bacteria. Hence, further studies on these molecular signatures should lead to the discovery of novel biochemical and physiological characteristics that are unique to these bacteria. The primary sequences of many of these genes/proteins that are specific for the Bacteroidetes or Chlorobi species are highly conserved and they provide novel means for identification of both known as well as novel species belonging to these groups by means of PCR-based and immunological methods. Several Bacteroidetes species play central role in the initiation and progression of periodontal diseases in humans $[12,18,19,58]$. Hence, the proteins that are specific to these bacteria also provide important potential targets for development of therapeutics and vaccines for treatment and prevention of periodontal diseases.

\section{Methods \\ Identification of Proteins that are Specific for Bacteroidetes and Chlorobi}

The blastp searches were carried out on each ORF in the genomes of $P$. gingivalis W83 [58], B. fragilis YCH46 [35], B. thetaiotaomicron VPI-5482 [15], G. forsetii KT080 [59], Chlorobium (Pelodictyon)luteolum DSM 273 and C. tepidum TLS [24], to identify proteins that are specific for the Bacteroidetes and Chlorobi phyla at different taxonomic levels. The blastp searches were performed against all organisms (i.e. using the NCBI non-redundant (nr) database) with default settings except that the low complexity filter was not used [71]. The proteins that were of interest were those where either all significant hits were from these groups of species or which involved a large increase in $\mathrm{E}$ values from the last Bacteroidetes-Chlorobi hit to the first hit from any other organism and the E values for the latter hits in most cases $>10^{-4}$, which indicates a weak similarity that could occur by chance. However, higher E values were sometimes acceptable particularly for smaller proteins as the magnitude of the E value depends upon the length of the query sequence. All promising proteins were further analyzed using the position-specific iterated (PSI)-blast program [71]. This program creates a position-specific scoring matrix from statistically significant alignments produced by the blastp program and then searches the database using this matrix. The PSI-blast is more sensitive in identifying weak but biologically relevant sequence similarity as compared to the blastp program [71]. In the present work, a protein was considered to be specific for a given group if all hits producing significant alignments were from that group of species. However, we have also retained a few proteins where 1 or 2 isolated species from 
other groups of bacteria also had acceptable E values, as they provide possible cases of lateral gene transfer. For all of the Bacteroidetes or Chlorobi-specific proteins identified in the present work, their protein ID's, accession numbers and any information regarding cellular functions (such as COG number or the presence of any conserved domain) are presented here. Preliminary sequence information regarding the presence of a homolog of a query protein in the partially sequenced genomes of $P$. intermedia, $P$. ruminicola and F. succinogenes subsp. succinogenes $S 85$ were obtained via genomic blasts against The Institute for Genomic Research database for unfinished microbial genomes [72]. In describing various proteins in the text, "PG," "BF," "BT," "orf", "Plut" and "CT" indicate the identification numbers of the proteins in the genomes of $P$. gingivalis W83, B. fragilis YCH46, B. thetaiotaomicron VPI5482,G. forsetii KT080, C. (Pelodictyon) luteolum DSM and C. tepidum TLS, respectively.

\section{Phylogenetic Analysis}

The amino acid sequences for the 12 conserved proteins viz. RNA polymerase $\beta$ subunit, RNA polymerase $\beta$ ' subunit (RpoC), alanyl-tRNA synthetase (AlaRS), arginyltRNA synthetase, phenylalanyl-tRNA synthetase, elongation factor-Tu, elongation factor $G$, RecA protein, DNA gyrase subunit A, DNA gyrase subunit B, Hsp60 or GroEL protein and DnaK or Hsp70 protein, for different species were downloaded from the NCBI database and aligned using the ClustalX (1.83) program using the default settings [73]. The sequences for two deep-branching species, $D$. radiodurans and T. aquaticus [27], were included in this dataset for rooting purposes. The sequence alignments for all 12 proteins were concatenated into a single large alignment containing 8899 positions. Poorly aligned regions from this alignment were removed with the Gblocks $0.91 \mathrm{~b}$ program [74], using the default settings, except that allowable gap position was selected to half. This resulted in a final sequence alignment of 6998 sites, which was used for phylogenetic analyses. A NJ tree based on this alignment (bootstrapped 1000 time) was constructed based on Kimura's model [75] using the TREECON programs [76]. Maximum-likelihood and MP trees were computed using the WAG+F model plus a gamma distribution with four categories [77] using the TREE-PUZZLE [78] and Mega 3.1 program [79], respectively. All trees were bootstrapped 100 times [80], unless otherwise indicated.

The character compatibility analysis on the concatenated alignment was carried out as described recently [57]. Using the program "DUALSITE" [57], all sites in the alignments where only two amino acid states were found, with each state present in at least two species, were selected. All columns with any gaps were omitted. The sites where one of the states is present in only a single species are not useful for compatibility analysis. All useful two state sites were converted into a binary file of " 0,1 " characters using the DUALSITE program and this file was used for compatibility analysis [57]. The compatibility analysis was carried out using the CLIQUE program from the PHYLIP (ver. 3.5c) program package [81] to identify the largest clique(s) of compatible characters. The cliques were drawn and the numbers of characters that distinguished different nodes were indicated. The sequence information for $G$. forsetii, which became available after these analyses were completed [59] is not included in these trees.

\section{Identification of conserved indels}

Multiple sequence alignments for large numbers of proteins have been created in our earlier work [82-84]. These alignments were visually inspected to search for any indels in a conserved region that was uniquely present in C. tepidum (the only Chlorobi species present in these groups). The specificity of any potential indel for these groups was evaluated by carrying out by blastp searches on a short segment of the sequence (between 80-120 aa) containing the indel and the flanking conserved regions against the nr database. The purpose of these blast searches was to obtain information from all available homologs to determine the specificities of the indels.

\section{Abbreviations}

$\mathrm{CD}$, conserved domain; CFB, Cytophaga-FlavobacteriaBacteroides; Indel, insert or deletion; ORF, open reading frame; ORFans, open reading frames of unknown functions; AlaRS, alanyl-tRNA synthetase; RGC, rare genetic change; RpoC, RNA polymerase $\beta$ '-subunit.

\section{Authors' contributions}

The initial blastp searches on various genomes were carried out by RSG with the computer assistance provided by Venus Wong. EL analyzed the results of these blast searches to identify various group-specific proteins and confirmed their specificities by means of PSI-blast and genomic blasts. RSG carried out the phylogenetic analyses and identified the conserved indels described here. RSG was also responsible for conceiving and directing this study and for the final evaluation of results. RSG was responsible for the preparation of the final manuscript. All authors have read and approved the submitted manuscript. 


\section{Additional material}

\section{Additional File 1}

A conserved indel ( 3 a a deletion) in ClpB protein that is mainly specific for the Bacteroidales, Flavobacteriales and Flexibacteraceae species. Partial sequence alignment of the ClpB protein containing this indel region is shown. The boxed region is missing in the Bacteroidales, Flavobacteriales and Flexibacteraceae species. Dashes in the alignment show identity with the amino acid on the top line. The ClpB homologs from $\mathrm{C}$. phaebacteroidetes and Methanospirillum hungatei also lack the boxed region, which could be due to LGT. The beta and gamma proteobacteria contain a larger insert in this region, which has likely occurred independently.

Click here for file

[http://www.biomedcentral.com/content/supplementary/14712148-7-71-S1.pdf]

\section{Additional File 2}

Proteins that are specific for the Bacteroides Genus. All significant hits for these proteins are from the following sequenced Bacteroides species unless otherwise indicated: B. thetaiotaomicron VPI-5482, B. fragilis NCTC 9343 and $\mathrm{YCH} 46$

Click here for file

[http://www.biomedcentral.com/content/supplementary/1471-

2148-7-71-S2.pdf]

\section{Additional file 3}

Proteins specific for Flavobacteria that are missing in several species. All significant hits for these proteins are also from Flavobacteriales species. However, unlike the proteins listed in Table 5, these proteins are either present in only a small number of Flavobacteria or are missing from many species.

Click here for file

[http://www.biomedcentral.com/content/supplementary/14712148-7-71-S3.pdf]

\section{Additional file 4}

Chlorobi-specific proteins that are missing in some species. All significant hits for these proteins are also from Chlorobi species. However, unlike the proteins listed in Table 6, these proteins are not present in all Chlorobi species.

Click here for file

[http://www.biomedcentral.com/content/supplementary/14712148-7-71-S4.pdf]

\section{Acknowledgements}

We thank Venus Wong and Yan Li for providing computer support for blast analyses and Beile Gao for help with some phylogenetic analysis. We thank the investigators at US DOE Joint Genome Institute and Gordon and Betty Moore Foundation Marine Biotechnology Initiative for making the genome data for various Bacteroidetes and Chlorobi species available in public databases prior to publication, which were of central importance in these studies. Blast searches against preliminary sequence data for the $P$. intermedia, $P$. ruminicola and $F$. succinogenes were performed at The Institute for Genomic Research website [72]. This work was supported by a research grant from the Canadian Institute of Health Research.

\section{References}

I. Garrity GM, Bell JA, Lilburn TG: The Revised Road Map to the Manual. In Bergey's Manual of Systematic Bacteriology, Volume 2, Part A, Introductory Essays Edited by: Brenner DJ, Krieg NR and Staley JT. New York, Springer; 2005: 159-220.

2. Woese CR: Bacterial evolution. Microbiol Rev 1987, 5 I:22 I-27I.

3. Ludwig W, Klenk HP: Overview: A phylogenetic backbone and taxonomic framework for prokaryotic systamatics. In Bergey's Manual of Systematic Bacteriology 2nd edition. Edited by: Boone DR and Castenholz RW. Berlin, Springer-Verlag; 200I:49-65.

4. Shah HN: The Genus Bacteroides and Related taxa. In The Prokaryotes Volume 196. 2nd edition. Edited by: Balows A, Truper HG, Dworkin M, Harder W and Schleifer KH. New York, Springer-Verlag; 1992:3593-3607.

5. Reichenbach H: The Order Cytophagales. In The Prokaryotes Volume 199. 2nd edition. Edited by: Balows A, Truper HG, Dworkin M, Harder $W$ and Schleifer KH. New York, Springer-Verlag; 1992:3631-3675.

6. Paster BJ, Dewhirst FE, Olsen I, Fraser GJ: Phylogeny of bacteroides, prevotella, and porphyromonas spp.and related bacteria. J Bacteriol 1994, 176:725-732.

7. Holdeman LV, Kelley RW, Moore WEC: Family I. Bacteroidaceae Pribam 1933. In Bergey's Manual of Systematic Bacteriology Ist edition. Edited by: Krieg NR and Holt JG. Baltimore, Williams and Wilkins; 1984:602-662.

8. Shah HN, Gharbia SE, Olsen I: Bacteroides, Prevotella, and Porphyromonas. In Topley \& Wilson's Microbiology and Microbial Infections, Volume 80. 10th edition. Edited by: Borrelio SP, Murray PR and Funke G. London, Hodder Arnold; 2005: 1913 - 1944.

9. Ohkuma M, Noda S, Hongoh Y, Kudo T: Diverse bacteria related to the bacteroides subgroup of the CFB phylum within the gut symbiotic communities of various termites. Biosci Biotechnol Biochem 2002, 66:78-84.

10. O'Sullivan LA, Weightman AJ, Fry JC: New degenerate Cytophaga-Flexibacter-Bacteroides-specific 165 ribosomal DNA-targeted oligonucleotide probes reveal high bacterial diversity in River Taff epilithon. Appl Environ Microbiol 2002, 68:201-210

II. Anton J, Oren A, Benlloch S, Rodriguez-Valera F, Amann R, RosselloMora R: Salinibacter ruber gen. nov., sp. nov., a novel, extremely halophilic member of the Bacteria from saltern crystallizer ponds. Int J Syst Evol Microbiol 2002, 52:485-49I.

12. Duncan MJ: Genomics of oral bacteria. Crit Rev Oral Biol Med 2003, I 4:175-187.

13. Oren A: The Genera Rhodothermus, Thermonema, Hymenobacter and Salinibacter. In The Prokaryotes: An Evolving Electronic Resource for the Microbiological Community 3rd, Release 3.3 edition. Edited by: Dworkin M and al . New York, Springer-Verlag; 2000.

14. Salyers AA: Bacteroides of the human lower intestinal tract. Annu Rev Microbiol 1984, 38:293-3।3.

15. Xu J, Bjursell MK, Himrod J, Deng S, Carmichael LK, Chiang HC, Hooper LV, Gordon Jl: A genomic view of the human-Bacteroides thetaiotaomicron symbiosis. Science 2003, 299:2074-2076

16. Cerdeno-Tarraga AM, Patrick S, Crossman LC, Blakely G, Abratt V, Lennard N, Poxton I, Duerden B, Harris B, Quail MA, Barron A, Clark L, Corton C, Doggett J, Holden MT, Larke N, Line A, Lord A, Norbertczak H, Ormond D, Price C, Rabbinowitsch E, Woodward J, Barrell $B$, Parkhill J: Extensive DNA inversions in the $B$. fragilis genome control variable gene expression. Science 2005, 307:1463-1465

17. Durmaz B, Dalgalar M, Durmaz R: Prevalence of Enterotoxigenic Bacteroides fragilis in patients with diarrhea: $A$ controlled study. Anaerobe 2005, I I:318-321.

18. Shah HN, Gharbia SE, Duerden BI: Bacteroides, Prevotella and Porphyromonas. In Topley \&Wilson's Microbiology and Microbial Infections vol. 2 Systematic Bacteriology Volume 58. 9th edition. Edited by: Balows A and Duerden BI. London, Arnold; I998: I 305-I330.

19. Paster BJ, Boches SK, Galvin JL, Ericson RE, Lau CN, Levanos VA, Sahasrabudhe A, Dewhirst FE: Bacterial diversity in human subgingival plaque. J Bacteriol 200I, 183:3770-3783.

20. Ximenez-Fyvie LA, Haffajee AD, Socransky SS: Microbial composition of supra- and subgingival plaque in subjects with adult periodontitis. J Clin Periodontol 2000, 27:722-732.

21. Overmann J, Garcia-Pichel F: The Phototrophic way of Life. The Prokaryotes: An Evolving Electronic Resource for the Microbiological Com- 
munity 3rd, Release 3.3 edition. 2000 [http://|4|.|50.157.|17:8080/ prokPUB/chaprender/jsp/showchap.jsp?chapnum=239]. New York, Springer-Verlag

22. Overmann J: The Family Chlorobiaceae. The Prokaryotes 3rd edition edition. 2003.

23. Truper HG, Pfennig N: The Family Chlorobiaceae. In The Prokaryotes Volume 195. 2nd edition. Edited by: Balows A, Truper HG, Dworkin M, Harder W and Schleifer KH. New York, Springer-Verlag; 1992:3583-3592.

24. Eisen JA, Nelson KE, Paulsen IT, Heidelberg JF, Wu M, Dodson RJ, DeBoy R, Gwinn ML, Nelson WC, Haft DH, Hickey EK, Peterson JD, Durkin AS, Kolonay JL, Yang F, Holt I, Umayam LA, Mason T, Brenner M, Shea TP, Parksey D, Nierman WC, Feldblyum TV, Hansen CL, Craven MB, Radune D, Vamathevan J, Khouri H, White O, Gruber TM, Ketchum KA, Venter JC, Tettelin H, Bryant DA, Fraser CM: The complete genome sequence of Chlorobium tepidum TLS, a photosynthetic, anaerobic, green-sulfur bacterium. Proc Natl Acad Sci U S A 2002, 99:9509-95। 4 .

25. Frostl JM, Overmann J: Phylogenetic affiliation of the bacteria that constitute phototrophic consortia. Arch Microbiol 2000, I 74:50-58.

26. Bryant DA, Frigaard NU: Prokaryotic photosynthesis and phototrophy illuminated. Trends Microbiol 2006, 1 4:488-496.

27. Olsen GJ, Woese CR, Overbeek R: The winds of (evolutionary) change: breathing new life into microbiology. J Bacteriol 1994, 176:1-6.

28. Gruber TM, Eisen JA, Gish K, Bryant DA: The phylogenetic relationships of Chlorobium tepidum and Chloroflexus auranticus based upon their RecA sequences. FEMS Microbiol Lett 1998, 162:53-60

29. Gupta RS, Mukhtar T, Singh B: Evolutionary relationships among photosynthetic prokaryotes (Heliobacterium chlorum, Chloroflexus aurantiacus, cyanobacteria, Chlorobium tepidum and proteobacteria): implications regarding the origin of photosynthesis. Mol Microbiol 1999, 32:893-906.

30. Gupta RS: The Phylogeny and Signature Sequences characteristics of Fibrobacters, Chlorobi and Bacteroidetes. Crit Rev Microbiol 2004, 30: 123-143.

31. Blankenship RE: Origin and early evolution of photosynthesis. Photosynthesis Research 1992, 33:91-III.

32. Frigaard NU, Chew AG, Li H, Maresca JA, Bryant DA: Chlorobium tepidum: insights into the structure, physiology, and metabolism of a green sulfur bacterium derived from the complete genome sequence. Photosynth Res 2003, 78:93-117.

33. Fenna RE, Matthews BW, Olson JM, Shaw EK: Structure of a bacteriochlorophyll-protein from the green photosynthetic bacterium Chlorobium limicola: crystallographic evidence for a trimer. J Mol Biol 1974, 84:23I-240.

34. Blankenship RE, Olson JM, Miller M: Antenna complexes from green photosynthetic bacateria. In Anoxygenic photosynthetic bacteria Edited by: Blankenship RE, Madigan MT and Bauer CE. Dordrecht, Kluwer; 1995:399-435.

35. Kuwahara T, Yamashita A, Hirakawa $\mathrm{H}$, Nakayama $\mathrm{H}$, Toh $\mathrm{H}$, Okada N, Kuhara S, Hattori M, Hayashi T, Ohnishi Y: Genomic analysis of Bacteroides fragilis reveals extensive DNA inversions regulating cell surface adaptation. Proc Natl Acad Sci U S A 2004 101:14919-14924.

36. Mongodin EF, Nelson KE, Daugherty S, DeBoy RT, Wister J, Khouri H, Weidman J, Walsh DA, Papke RT, Sanchez PG, Sharma AK, Nesbo CL, MacLeod D, Bapteste E, Doolittle WF, Charlebois RL, Legault B, Rodriguez-Valera F: The genome of Salinibacter ruber: Convergence and gene exchange among hyperhalophilic bacteria and archaea. Proc Natl Acad Sci U S A 2005, 102:18147-18152.

37. Kainth P, Gupta RS: Signature Proteins that are Distinctive of Alpha Proteobacteria. BMC Genomics 2005, 6:94.

38. Griffiths E, Ventresca MS, Gupta RS: BLAST screening of chlamydial genomes to identify signature proteins that are unique for the Chlamydiales, Chlamydiaceae, Chlamydophila and Chlamydia groups of species. BMC Genomics 2006, 7:14.

39. Gao B, Parmanathan R, Gupta RS: Signature proteins that are distinctive characteristics of Actinobacteria and their subgroups. Antonie van Leeuwenhoek 2006, (In press):

40. Gupta RS: Molecular signatures (unique proteins and conserved Indels) that are specific for the epsilon proteobacteria (Campylobacterales). BMC Genomics 2006, 7:167.
4I. Gao B, Gupta RS: Signature Proteins for Archaea and Its Main Subgroups and the Origin of Methanogenesis. BMC Genomics 2007, 8:86.

42. Oren A: Prokaryote diversity and taxonomy: current status and future challenges. Philos Trans R Soc Lond B Biol Sci 2004, 359:623-638.

43. Gupta RS, Griffiths E: Critical Issues in Bacterial Phylogenies. Theor Popul Biol 2002, 61:423-434.

44. Ragan MA, Charlebois RL: Distributional profiles of homologous open reading frames among bacterial phyla: implications for vertical and lateral transmission. Int J Syst Evol Microbiol 2002, 52:777-787.

45. Imhoff JF: Phylogenetic taxonomy of the family Chlorobiaceae on the basis of I6S rRNA and fmo (Fenna-Matthews-Olson protein) gene sequences. Int I Syst Evol Microbiol 2003, 53:94I-95I.

46. Overmann J, Tuschak C: Phylogeny and molecular fingerprinting of green sulfur bacteria. Arch Microbiol 1997, 167:302-309.

47. Alexander B, Andersen JH, Cox RP, Imhoff JF: Phylogeny of green sulfur bacteria on the basis of gene sequences of $16 \mathrm{~S}$ rRNA and of the Fenna-Matthews-Olson protein. Arch Microbiol 2002, 178: $13 \mid-140$.

48. Gruber TM, Bryant DA: Molecular systematic studies of eubacteria, using s70- type sigma factors of group I and group 2. Bacteriol 1997, I79: 1734-1747.

49. Suzuki M, Nakagawa Y, Harayama S, Yamamoto S: Phylogenetic analysis and taxonomic study of marine Cytophaga-like bacteria: proposal for Tenacibaculum gen. nov with Tenacibaculum maritimum comb. nov and Tenacibaculum ovolyticum comb. nov., and description of Tenacibaculum mesophilum sp nov and Tenacibaculum amylolyticum sp nov. Int J Syst Evol Microbiol 200I, 5 I:I639-I652.

50. Rokas A, Williams BL, King N, Carroll SB: Genome-scale approaches to resolving incongruence in molecular phylogenies. Nature 2003, 425:798-804

5I. Felsenstein J: Inferring phylogenies from protein sequences by parsimony, distance, and likelihood methods. Methods in Enzymology 1996, 266:4 I 8-27:4|8-427.

52. Felsenstein J: Inferring Phylogenies Sunderland, Mass., Sinauer Associates, Inc.; 2004.

53. Le Quesne WJ: The uniquely evolved character concept and its cladistic application. Systematic Zoology 1975, 23:5।3-5 I7.

54. Sneath PHA, Sackin MJ, Ambler RP: Detecting evolutionary incompatibilities from protein sequences. Systematic Zoology 1975, 24:3|I-332.

55. Estabrook GF, Johnson CSJ, McMorris FR: A mathematical foundation for the analysis of cladistic character compatibility. Mathematical Biosciences 1976, 29:18I-187.

56. Meacham CA, Estabrook GF: Comaptibility methods in Systematics. Ann Rev Ecol Syst 1985, 16:43 1-446.

57. Gupta RS, Sneath PHA: Application of the character compatibility approach to generalized molecular sequence data: Branching order of the proteobacterial subdivisions. J Mol Evol 2006, 64:90-100.

58. Nelson KE, Fleischmann RD, DeBoy RT, Paulsen IT, Fouts DE, Eisen JA, Daugherty SC, Dodson RJ, Durkin AS, Gwinn M, Haft DH, Kolonay JF, Nelson WC, Mason T, Tallon L, Gray J, Granger D, Tettelin H, Dong H, Galvin JL, Duncan MJ, Dewhirst FE, Fraser CM: Complete genome sequence of the oral pathogenic bacterium Porphyromonas gingivalis strain W83. J Bacteriol 2003, 185:559I-560I.

59. Bauer M, Kube M, Teeling H, Richter M, Lombardot T, Allers E, Wurdemann CA, Quast C, Kuhl H, Knaust F, Woebken D, Bischof K, Mussmann M, Choudhuri JV, Meyer F, Reinhardt R, Amann RI, Glockner FO: Whole genome analysis of the marine Bacteroidetes'Gramella forsetii' reveals adaptations to degradation of polymeric organic matter. Environ Microbiol 2006, 8:220I-22I3.

60. Marchler-Bauer A, Bryant SH: CD-Search: protein domain annotations on the fly. Nucleic Acids Res 2004, 32:W327-W33I.

6I. Galperin MY, Koonin EV: Who's your neighbor? New computational approaches for functional genomics. Nat Biotechnol 2000, 18:609-613.

62. Danchin A: From protein sequence to function. Curr Opin Struct Biol 1999, 9:363-367. 
63. Nishikawa K, Yoshimura F, Duncan MJ: A regulation cascade controls expression of Porphyromonas gingivalis fimbriae via the FimR response regulator. Mol Microbiol 2004, 54:546-560.

64. Gogarten JP, Doolittle WF, Lawrence JG: Prokaryotic evolution in light of gene transfer. Mol Biol Evol 2002, 19:2226-2238.

65. Gogarten JP, Townsend JP: Horizontal gene transfer, genome innovation and evolution. Nat Rev Microbiol 2005, 3:679-687.

66. Bruck I, Goodman MF, O'Donnell M: The essential C family DnaE polymerase is error-prone and efficient at lesion bypass. J Biol Chem 2003, 278:4436I-44368.

67. Daubin V, Ochman H: Bacterial genomes as new gene homes: the genealogy of ORFans in E. coli. Genome Res 2004, 14:1036-1042.

68. Beiko RG, Harlow TJ, Ragan MA: Highways of gene sharing in prokaryotes. Proc Natl Acad Sci U S A 2005, I 02: | 4332-I 4337.

69. Griffiths $E$, Gupta RS: The use of signature sequences in different proteins to determine the relative branching order of bacterial divisions: evidence that Fibrobacter diverged at a similar time to Chlamydia and the Cytophaga- Flavobacterium-Bacteroides division. Microbiology 200I, I 47:26II-2622.

70. Gupta RS: Evolutionary Relationships Among Photosynthetic Bacteria. Photosynth Res 2003, 76:173-183.

7I. Altschul SF, Madden TL, Schaffer AA, Zhang J, Zhang Z, Miller W, Lipman DJ: Gapped BLAST and PSI-BLAST: a new generation of protein databases search programs. Nucleic Acids Research 1997, 25:3389-3402

72. TIGR: TIGR Unfinished Microbial Genome Database. 2007 [http://www.tigr.org/tdb/ufmg/index.shtml].

73. Jeanmougin F, Thompson JD, Gouy M, Higgins DG, Gibson TJ: Multiple sequence alignment with Clustal $\mathbf{x}$. Trends Biochem Sci 1998, 23:403-405.

74. Castresana J: Selection of conserved blocks from multiple alignments for their use in phylogenetic analysis. Mol Biol Evol 2000, 17:540-552.

75. Kimura M: The Neutral Theory of Molecular Evolution Cambridge, Cambridge University Press; 1983.

76. Van de PY, De Wachter R: TREECON for Windows: a software package for the construction and drawing of evolutionary trees for the Microsoft Windows environment. Comput Appl Biosci 1994, 10:569-570.

77. Whelan S, Goldman N: A general empirical model of protein evolution derived from multiple protein families using a maximum-likelihood approach. Mol Biol Evol 200I, I 8:69I-699.

78. Schmidt HA, Strimmer K, Vingron M, von Haeseler A: TREE-PUZZLE: maximum likelihood phylogenetic analysis using quartets and parallel computing. Bioinformatics 2002, 18:502-504.

79. Kumar S, Tamura K, Nei M: MEGA3: Integrated software for molecular evolutionary genetics analysis and sequence alignment. Brief Bioinform 2004, 5:150-163.

80. Felsenstein J: Confidence limits in phylogenies: an approach using the bootstap. Evolution 1985, 39:783-79I.

8I. Felsenstein J: PHYLIP, version 3.5c. Seattle, WA, University of Washington; 1993.

82. Gupta RS: Protein Phylogenies and Signature Sequences: A Reappraisal of Evolutionary Relationships Among Archaebacteria, Eubacteria, and Eukaryotes. Microbiol Mol Biol Rev 1998, 62:|435-|49|.

83. Gupta RS: The phylogeny of Proteobacteria: relationships to other eubacterial phyla and eukaryotes. FEMS Microbiol Rev 2000, 24:367-402

84. Gupta RS, Pereira M, Chandrasekera C, Johari V: Molecular signatures in protein sequences that are characteristic of Cyanobacteria and plastid homologues. Int J Syst Evol Microbiol 2003, 53: $1833-1842$
Publish with Bio Med Central and every scientist can read your work free of charge

"BioMed Central will be the most significant development for disseminating the results of biomedical research in our lifetime. "

Sir Paul Nurse, Cancer Research UK

Your research papers will be:

- available free of charge to the entire biomedical community

- peer reviewed and published immediately upon acceptance

- cited in PubMed and archived on PubMed Central

- yours - you keep the copyright
BiolMedcentral 